\title{
The Influence of Water-Jet Modification of Soil Conditions on Reduction of Vibrations during Sheet Pile Driving in the Subsoil
}

\author{
Artur Jaroń1 ${ }^{1}$, Małgorzata Jastrzębska², Marian Łupieżowiec ${ }^{2}$ \\ ${ }^{1}$ Zakład Robót Inżynieryjnych Henryk Chrobok i Hubert Chrobok sp. j., ul. Gościnna 101, Bojszowy Nowe, Poland \\ ${ }^{2}$ Silesian University of Technology, Faculty of Civil Engineering, Department of Geotechnics and Roads, \\ ul. Akademicka 5, Gliwice, Poland \\ Email: malgorzata.jastrzebska@polsl.pl
}

How to cite this paper: Jaroń, A., Jastrzębska, M. and Łupieżowiec, M. (2018) The Influence of Water-Jet Modification of Soil Conditions on Reduction of Vibrations during Sheet Pile Driving in the Subsoil. World Journal of Engineering and Technology, 6, 17-49.

https://doi.org/10.4236/wjet.2018.61002

Received: December 3, 2017

Accepted: December 31, 2017

Published: January 3, 2018

Copyright $\odot 2018$ by authors and Scientific Research Publishing Inc. This work is licensed under the Creative Commons Attribution International License (CC BY 4.0).

http://creativecommons.org/licenses/by/4.0/

(c) $\underset{\mathrm{EY}}{\mathrm{i}}$ Open Access

\begin{abstract}
Vibratory driving is the most efficient method of sheet pile installation. The elimination or at least reduction of harmful consequences of sheet pile vibratory driving becomes an increasingly important and often the decisive factor in the selection of the excavation protection technology. In difficult soil conditions with strength soil parameters, pressure water jetting precedes sheet pile driving. This technique changes the soil properties, destroying its existing structure near the installed sheet pile. Unfortunately, the results and achievements of contractors using this technique are very often held confidential or simply remain in the records and it is difficult to find papers on this subject. This article features a detailed description of jet-assisted sheet pile driving, including a prefabrication description for the sheet pile toe used to jet water through, water pressure and quantity data and the results with regard to reduce vibrations and noise, as well as to the increase in sheet pile vibratory driving performance.
\end{abstract}

\section{Keywords}

Sheet Piles, Vibratory Sheet Pile Driving, Reduction of Vibrations

\section{Introduction}

Vibratory driving is the most efficient method of sheet pile installation [1]. The advantages of this method are simplicity, speed, correction possibilities, as well as gentle material handling in comparison to impact driving and hydraulic press-in. 
Due to the rising concern with the environment and projects being located in urban areas, close to existing buildings, the elimination or at least reduction of harmful consequences of sheet pile vibratory driving becomes an increasingly important and often the decisive factor in the selection of the excavation protection technology.

Free-hanging and leader-mounted vibrators (Figure 1(a) and Figure 1(b)) are the two most common methods of sheet pile vibratory driving. Each machine consists of a vibrator, a hydraulic power unit, high-pressure hoses, a hydraulic clamp and a vibrating hammer carrier, i.e. wheeled crane (Figure 1(a)) or a pile driver with a mast (Figure $1(\mathrm{~b})$ ). Additionally, the machine can be supplemented with additional equipment, e.g. a low or high pressure pump $[2]$.

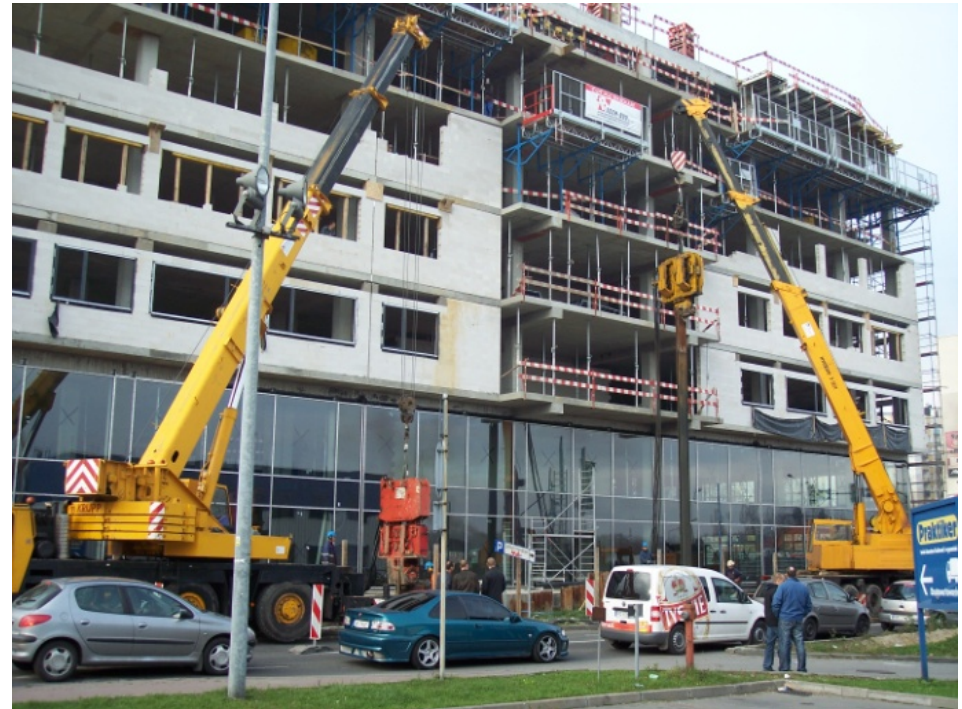

(a)

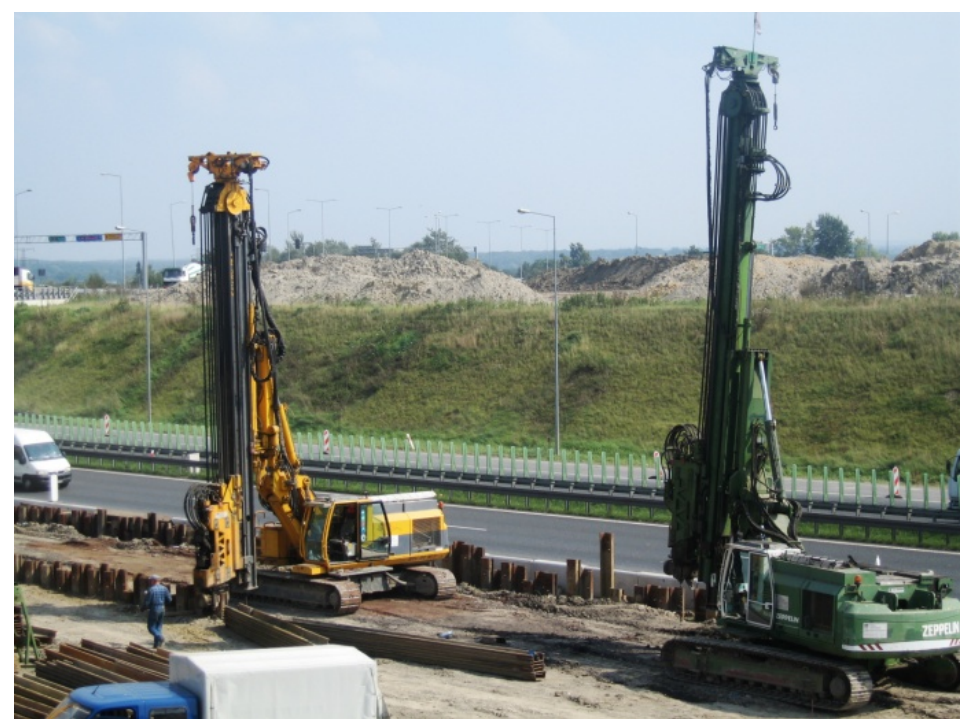

(b)

Figure 1. (a) Free-hanging vibrator; (b) Leader-mounted vibrator. 
The vibrating hammer drive force is crucial to the sheet pile installation operation. If the soil resistance equilibrates the sheet pile drive force, then the sheet pile installation is subject to difficulties. This may result in further negative consequences of vibratory driving, namely vibrations or noise stretching over extended time.

The vibration propagation pattern is always the same and it consists of: the transmitter, e.g. the source of vibration, the transmission medium, e.g. the soil, and the receiver, namely structures and/or people [3] (Figure 2).

The models used to project the vibrations caused by sheet pile vibratory driving are still subject to extensive research and numerous publications.

It is possible to reduce the negative impact on the environment at every stage, i.e. at the vibration source, at the propagation stage and at the receiver, i.e. structures and/or people.

For example, modern vibrating hammers operate at high frequencies (approx. $38-40 \mathrm{~Hz}$ ). During start-up and shut-down through a system of moveable counterweights, they do not work at interim frequencies, i.e. from $0 \mathrm{~Hz}$ to approx. $38 \mathrm{~Hz}$. The vibrations occur already at the maximum frequency, contrary to the legacy machines, in which the interim frequencies during the start-up and shut-down process caused resonance hazard to structures. This is an example of counteraction to the negative consequences vibrations at their source.

It is also possible to reduce vibrations at the structure that may be subject to dynamic influence in the future. This is a standard procedure in areas affected by earthquakes or mining damages. A typical example would be to place the structure on slab foundation instead of spot or continuous footing. This is counteracting the impact of vibrations at the receiver through additional load

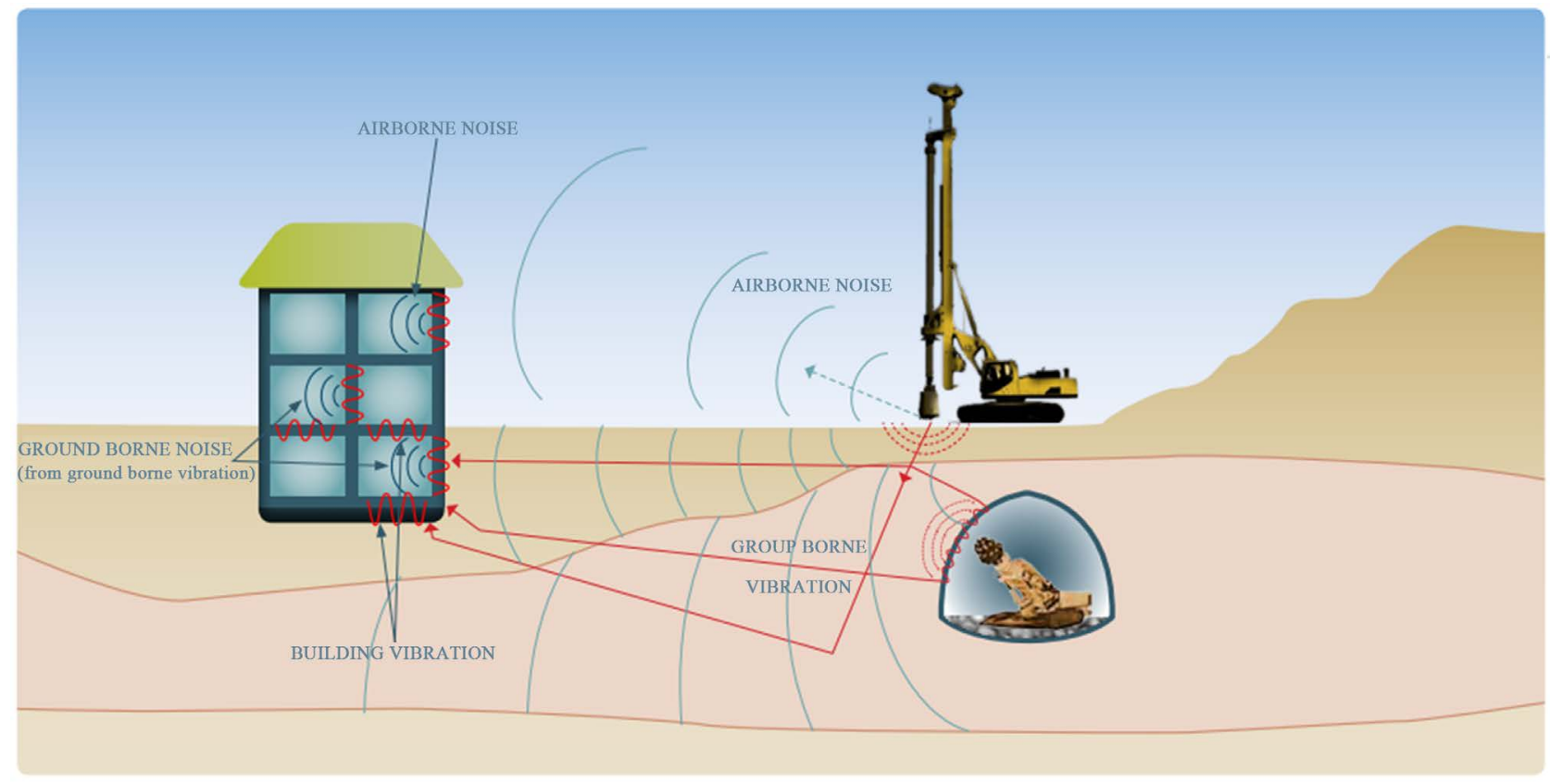

Figure 2. Propagation of vibrations and noise [4]. 
and stiffness in the structure.

Moreover, it vibrations may be reduced by using underground protective barriers, e.g. open trenches, filled trenches (with concrete or bentonite), barriers of steel sheet piles and pile walls.

This article considers the possibility of reducing vibrations at the stage of interaction between the sheet pile and the soil, which may be classified as vibration reduction at the source.

In difficult soil conditions, with strength soil parameters, pressure jetting or pre-drilling precedes sheet pile driving. Both techniques change the soil property, destroying its existing structure near the installed sheet pile.

Pressure jet-assisted sheet pile driving, a technique that has been known for decades, is of interest to the Authors and constitutes the subject of this article. The principle of this technique is to feed water through small diameter pipes along the sheet pile, to its toe. The water jet loosens the soil precisely below the sheet pile toe and lubricates its lateral surface. There are many methods of using this technique. Utmost care should be taken, because the side effect is the loosening of the soil surrounding the sheet pile. A change soil properties in an excessive area around the sheet piles is undesirable, because in can disrupt e.g. the excavation shoring structure static diagram.

Initially, in the 1960s, contractors would use pipes with the diameter of up to 4 inches to supply large amounts of water to the soil. Consequently, the soil properties were much worse than originally. Controlled feeding of the water medium was applied in 1970s in Munich [5]. Unfortunately, the results and achievements of contractors using this technique are very often held confidential or simply remain in the records and it is difficult to find papers on this subject.

This article features a detailed description of jet-assisted sheet pile driving, including a prefabrication description for the sheet pile toe used to jet water through, water pressure and quantity data and the results with regard to vibrations and noise, as well as to the increase in sheet pile vibratory driving performance.

Noise pollution generated through construction works may cause health damage and annoyance in people nearby the construction site and above all in the workers themselves. This article, apart from vibration measurements, includes a noise measurement performed at the distance of $10 \mathrm{~m}$ from the source, as well as the answer to the question, whether pressure jet-assisted sheet piles reduced not only the vibration level, but also the noise level.

\section{Objective and Scope}

There are no general solutions to the problems related to dynamic influence that could be applied to every construction site. Each case has to be considered individually. The legal basis of determining allowable dynamic influence on structures is included in numerous European standards. The allowable vibration levels are usually given in the vibration velocity unit, Peak Particle Veloc- 
ity (in short: PPV) $[\mathrm{mm} / \mathrm{s}]$. Approaching and exceeding those values could cause cracking in plasters and façades, while a significant excess in extreme cases can lead to structure construction elements damage. The PPV value usually is the highest vibration velocity measurement [6]. In some cases, the PPV value is interpreted as the resultant of vibration velocity in three, mutually perpendicular direction [7] [8]. Ground vibrations, as well as noise, can also cause human disturbance. Numerous European standards indicates threshold values with regard to human sensitivity (Figure 3 and Figure 4). While it is easier to determine threshold values for structures, for human beings these values are to a large extent estimates. Some vibration levels could be perfectly acceptable to one person and unacceptable to another one. According to noise level humans can hear sounds between 0 and 140 decibels. 0 decibel does not

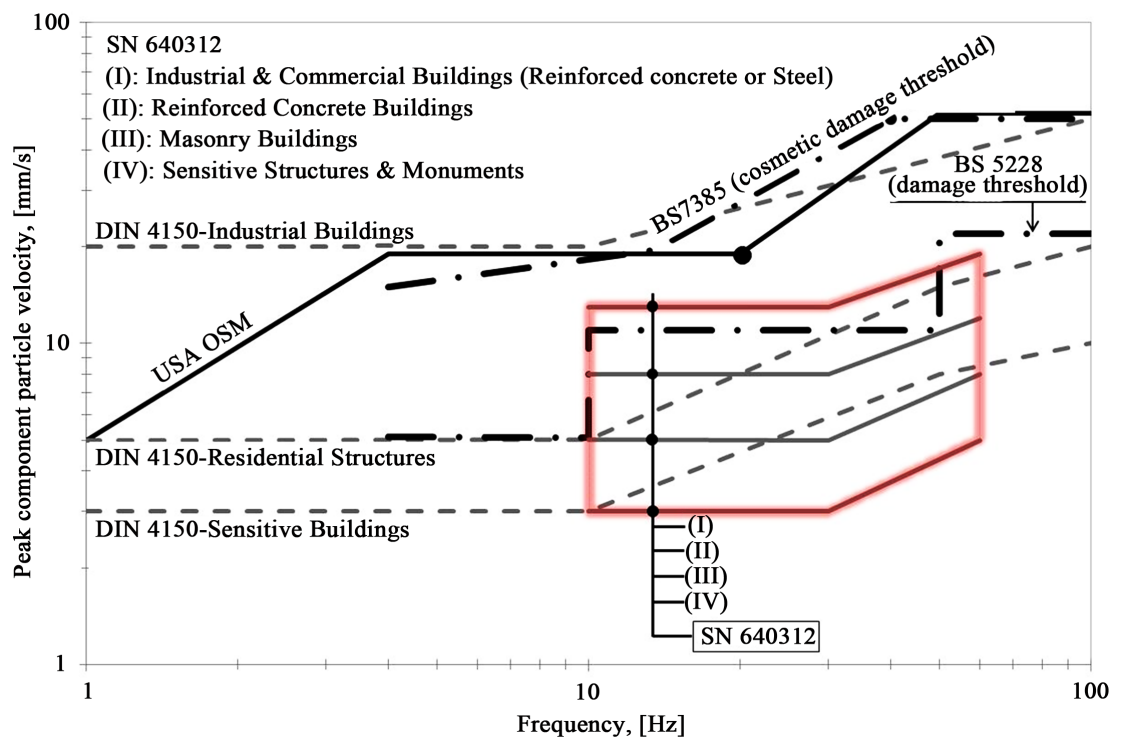

(a)
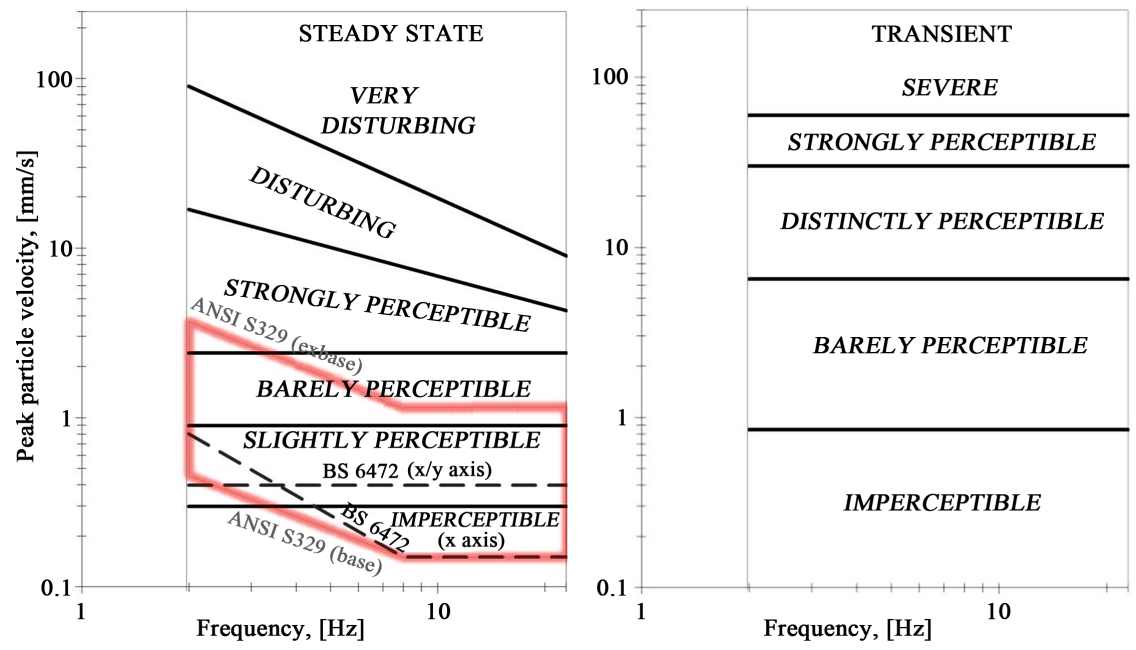

(b)

Figure 3. Comparison of various threshold vibration criteria for structural damage and human disturbance [6]. 


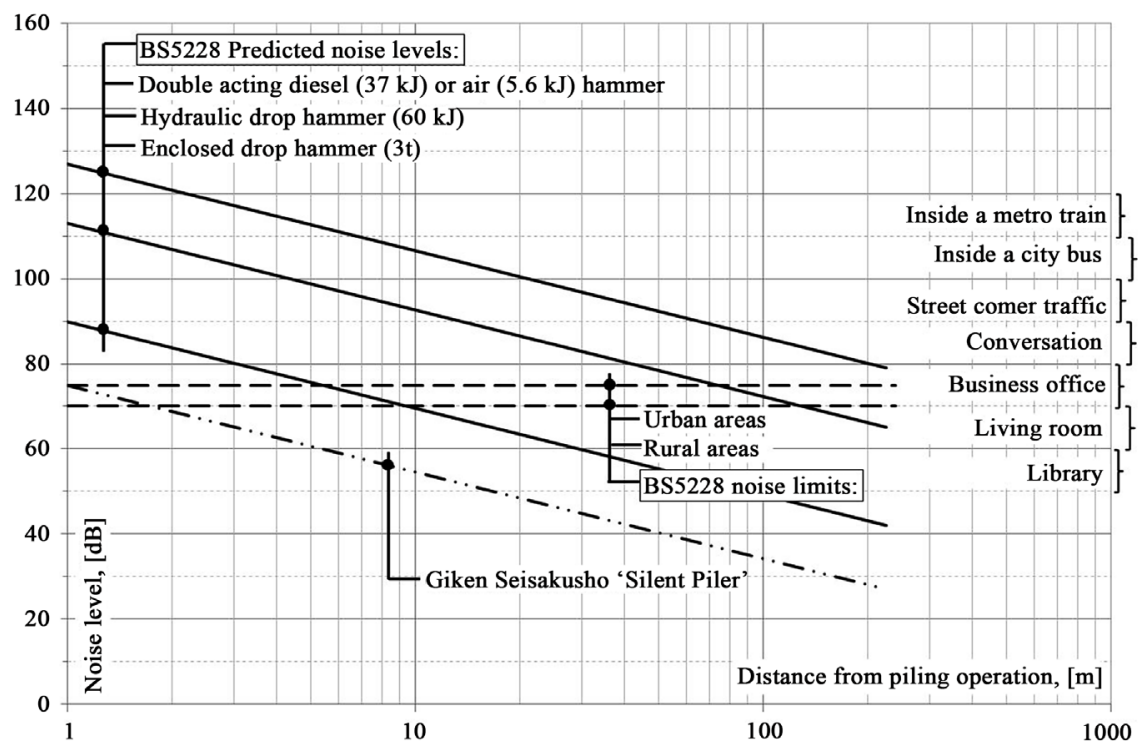

Figure 4. Variation of noise level with the distance from various types of piling operation [7].

mean that there is no sound, merely that we cannot hear it. 0 decibel is the so-called hearing threshold for the human ear. While we can hear more than 140 decibels, it is too painful for our ears and if you expose yourself to such a loud noise you are at extremely high risk of permanent damage to your hearing. Variation of noise level with the distance from various types of piling operation is shown in Figure 4.

Most standards and technical literature defines allowable thresholds as a function of vibration velocity and frequency, at which these vibrations occur.

For example, following Athanasopoulos and Pelekis [6], in one case the measured particle velocity was $20 \mathrm{~mm} / \mathrm{s}$ at the frequency of approx. $20 \mathrm{~Hz}$ (Figure 3). This value coincides with the USA OSM limit and it is lower than the BS7385 limit. At this site, some minor cracks on the brick walls of a three-floor reinforced concrete building and settlement on the walkway adjacent to the building were observed. Similar examples prove that the limits indicated in standards are only reference values and they do not guarantee $100 \%$ safety. While approaching the limits, one should analyse the possibility to reduce vibrations by $10 \%-20 \%$, because this could be crucial to the final success of the construction works.

Nowadays high frequency vibrating hammers are standard. High vibration frequency of approx. $38 \mathrm{~Hz}$ moves the PPV value in comparison to legacy machines operating at $20 \mathrm{~Hz}$, which allows to accept higher PPV values. Nonetheless, caution should be maintained.

Construction standards usually include vibration limits for distinct structure types, such as historic buildings, residential buildings, commercial and/or industrial buildings (Figure 5). This division is necessary due to the diverse sensitivity of these objects to dynamic influence. Apart from the structure 


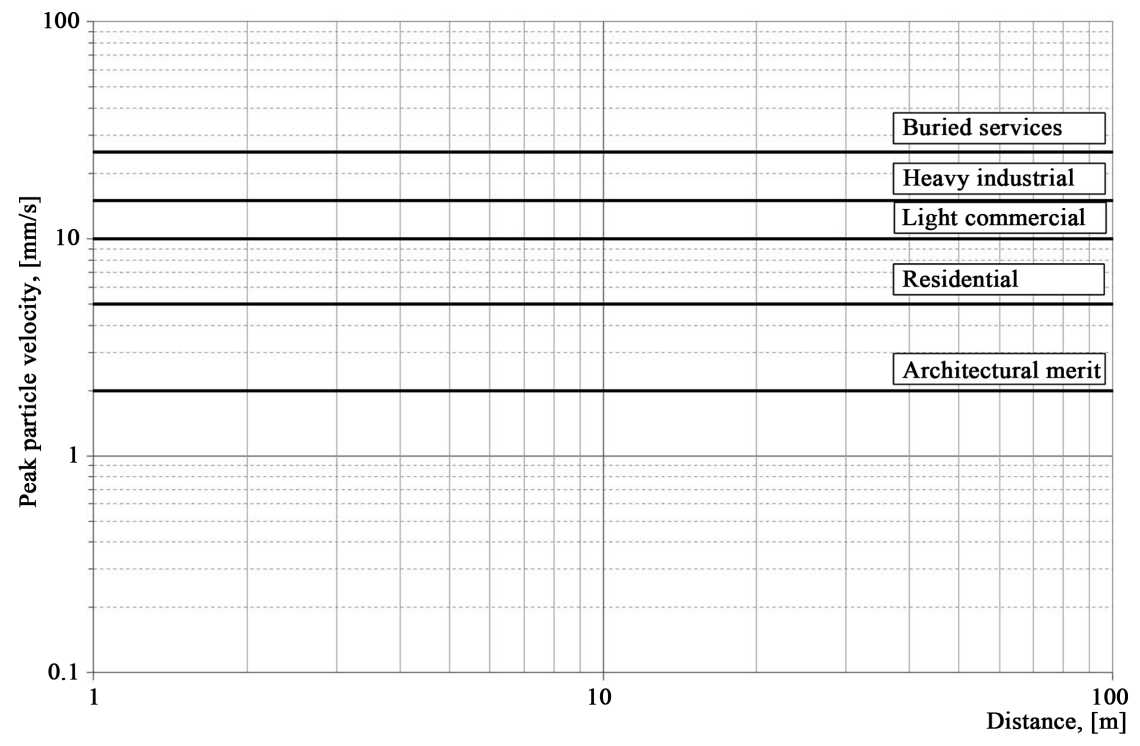

Figure 5. Eurocode 3: Maximum acceptable vibrations to avoid structural damage [9].

function, measured vibrations are affected by such factors as building weight, foundation type, construction materials etc. As mentioned in the introduction, this article considers the possibility to reduce vibrations at their source, during the interaction between the sheet pile and the soil. Therefore, in order to prevent these factors from determining the results, the PPV values were measured at the soil surface. A logical assumption was made, that the reduction in vibrations in the soil indicates that the measured vibrations has also decreased at the structure.

Measurements were made at three points, at the distance of $5 \mathrm{~m}, 10 \mathrm{~m}$ and 15 $\mathrm{m}$ (Figure 6). No underground and aboveground obstacles, such as foundations, pipelines, walkways etc. were found. In order to assure precise measurements, they were made in three different directions, using 3 geophones. For detailed description of geophones, see Section 4 . The first step was to compare measurement results of different instruments. Therefore before the beginning of the tests, all 3 geophones were placed at the distance of $10 \mathrm{~m}$ from the source of vibrations, i.e. the sheet pile vibration driving point.

The results, consisting of PPV measurements at the interval of 10 seconds, are shown in Figures $7(a)-(c)$. The differences between measurements are attributed to such factors as differences in stand setting on the ground and the stochastic character of the soil. Furthermore the measuring instruments had been produced by different manufacturers and calibrated in different periods of time. Some measurement points are $100 \%$ discrepant and some are consistent.

The main objective of the research was to verify the impact of jet-assisted sheet pile driving on vibration reduction, sheet pile installation and possible noise reduction. Hence, insignificant differences among the geophones shown in Figures $7(a)-(c)$ are not cause for concern.

During the essential tests, 13 sheet piles were installed. The type of sheet piles used and the order, in which they were installed, is shown in Figure 8. GU20N 

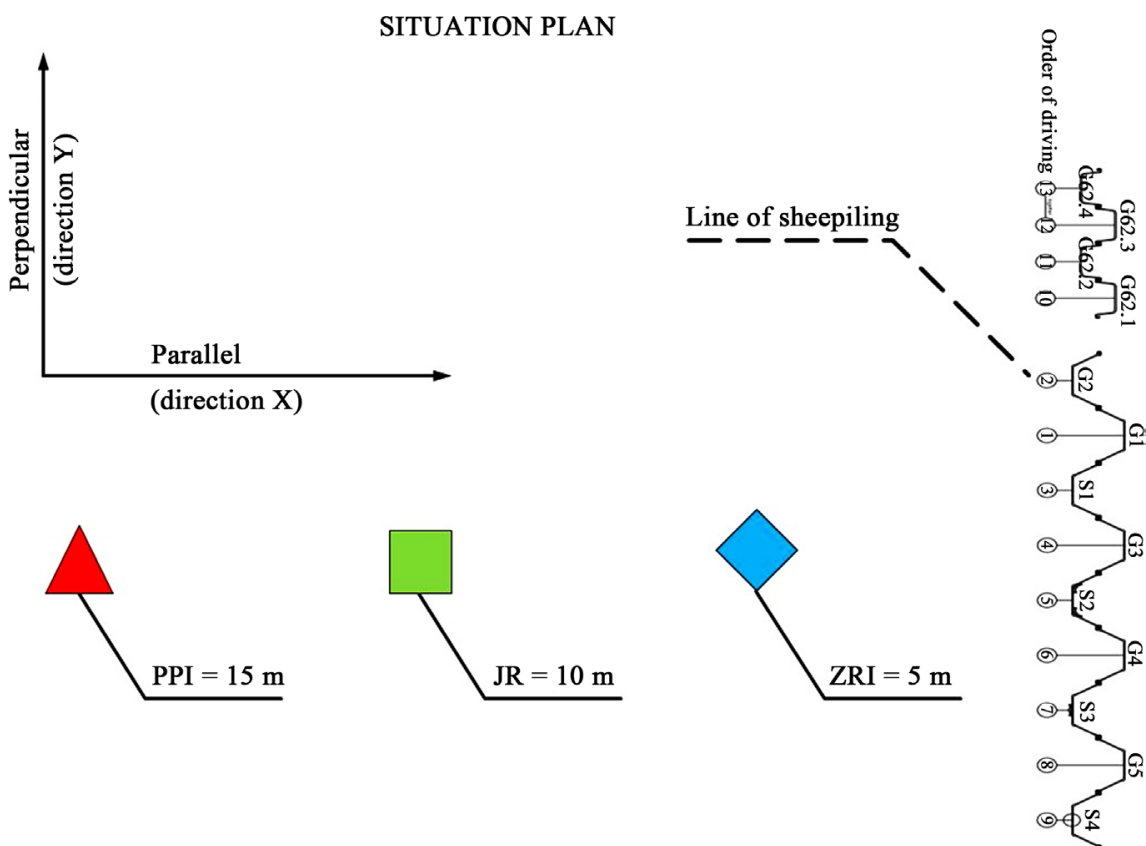

Figure 6. Situation plan (order of driving sheet piles-Figure 8).

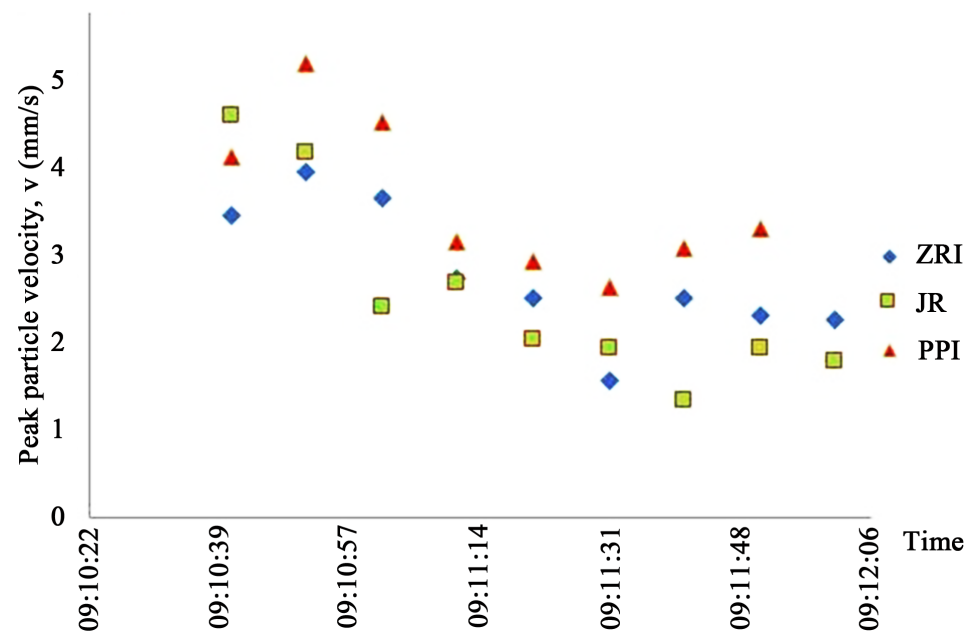

(a)

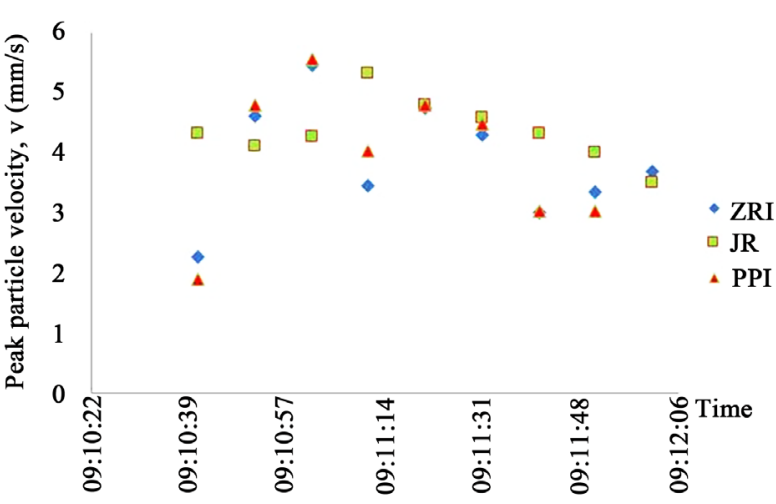

(b)

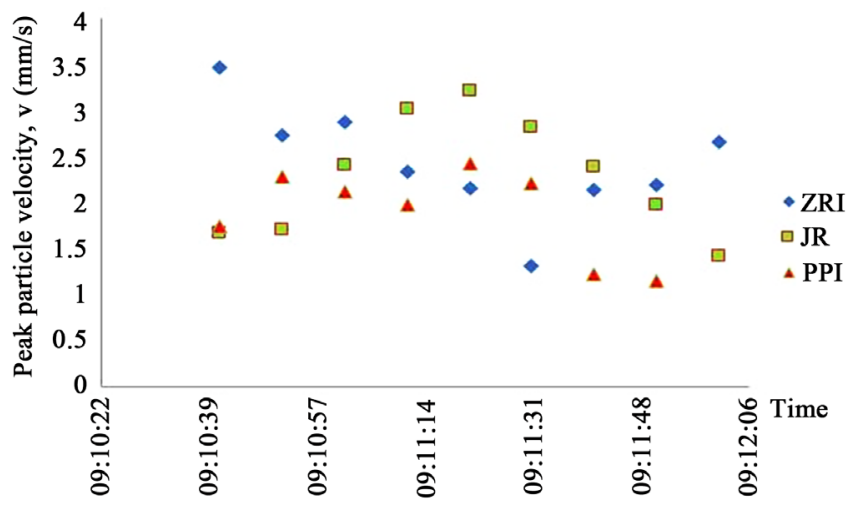

(c)

Figure 7. Comparison of 3 different geophones: (a) vertical direction (Z); (b) radial direction (X); (c) transverse direction (Y). 

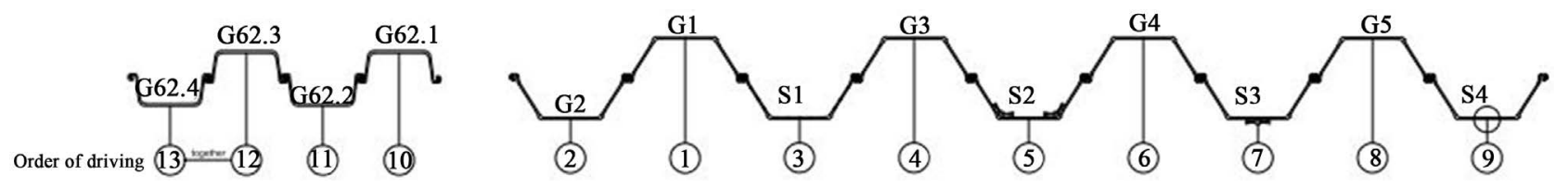

Figure 8. Order of driving sheet piles GU20N (G and S symbol) and GU16-400 (G62 symbol).

type sheet piles were new. GU16-400 type sheet piles had been used several times in the past and their clutches were in poor condition. The difference between the new and used sheet pile clutches is shown in Figure 9.

4 of the GU20N sheet piles were made with different tubes to feed water to the sheet pile toe. The sheet piles were marked with letters S1, S2, S3 and S4. For detailed description, drawings and pictures of these sheet piles, see Table 1.

It had been decided to perform measurements at the soil surface in order to avoid structural effects of the particular buildings (their dimensions, foundation, construction materials) on vibration propagation and results. Moreover, the influence of sheet pile vibratory driving was evaluated in people in direct vicinity, especially in employees that were the most exposed to vibrations and noise.

The analysis of ground vibration propagation is not the subject of this article. Nonetheless, it is worth noting that the vibration values at the distance of $15 \mathrm{~m}$ from the source are much higher than at the distance of $10 \mathrm{~m}$ (Appendix A, Appendix B). In fact, the values at the distance of $15 \mathrm{~m}$ are close to those at $5 \mathrm{~m}$. It was clearly felt by all research participants.

\section{Ground Vibration Propagation}

The sources of vibrations, such as sheet pile vibratory driving, generate body waves and surface waves that propagate in the soil. Longitudinal waves and transverse waves (respectively: P-waves and S-waves) are the main types of waves considered at the relatively short distance from the vibration source. Surface waves, the most important of which is the Rayleigh wave (R-waves), propagate at the soil surface. With respect to structures, the Rayleigh wave is the most useful due to the fact that structure foundations are generally placed directly under the soil surface [3] [10]. Besides, surface waves transfer more than $66 \%$ of all energy carried by waves, so their influence on the measured PPV values is dominant. Also for this reason, an anti-vibration screen of apparently insignificant size in the ground or a simple trench constitute efficient anti-vibration barriers and significantly reduce further wave propagation. Considering this phenomenon, it seems that performing measurements at the soil surface is the most sensible solution.

The propagation mechanism of seismic waves generated by vibratory or impact pile driving is shown in Figure 10 [11].

The process of pile vibratory driving process is controlled by three components shown in Figure 11, namely: 1) the pile (sheet pile) to be driven, 2) the vibrator and 3) soil conditions [12]. 
Table 1. Jet-assisted sheet piles

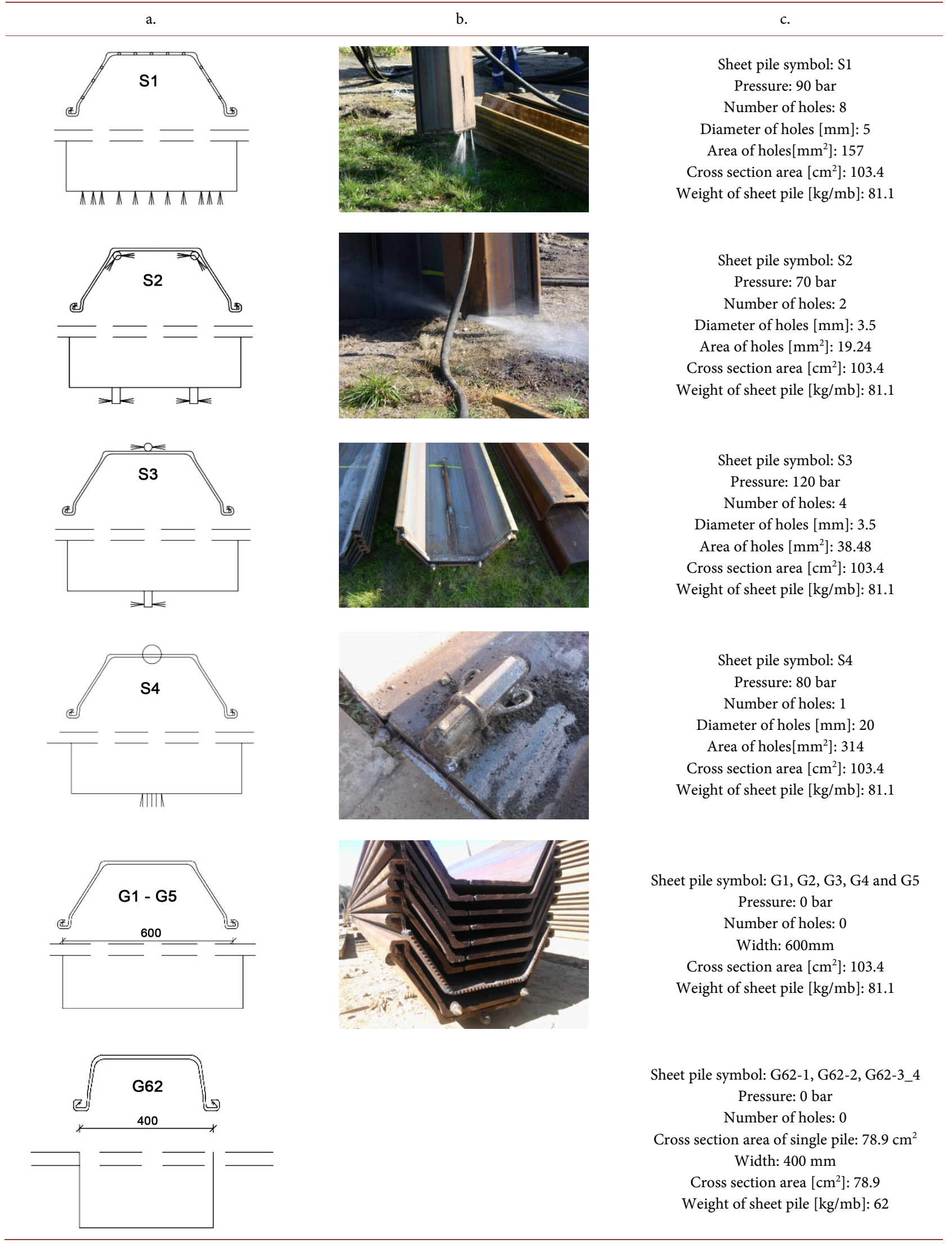




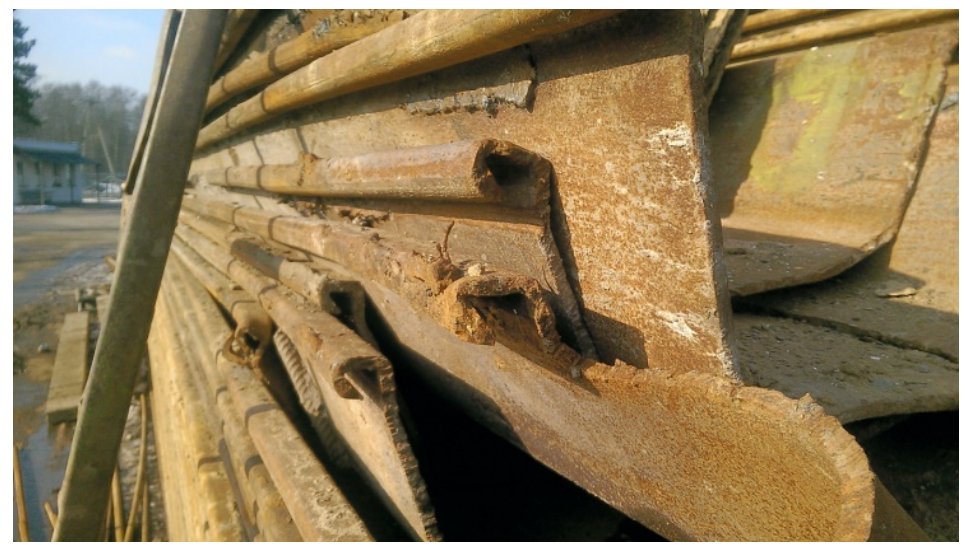

(a)

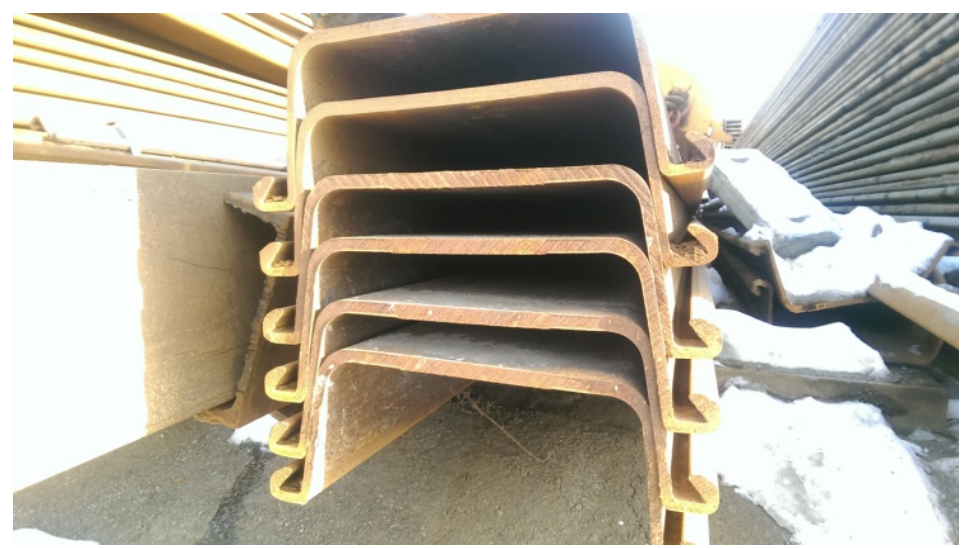

(b)

Figure 9. Clutches of several used sheet piles (a) and new sheet piles (b).

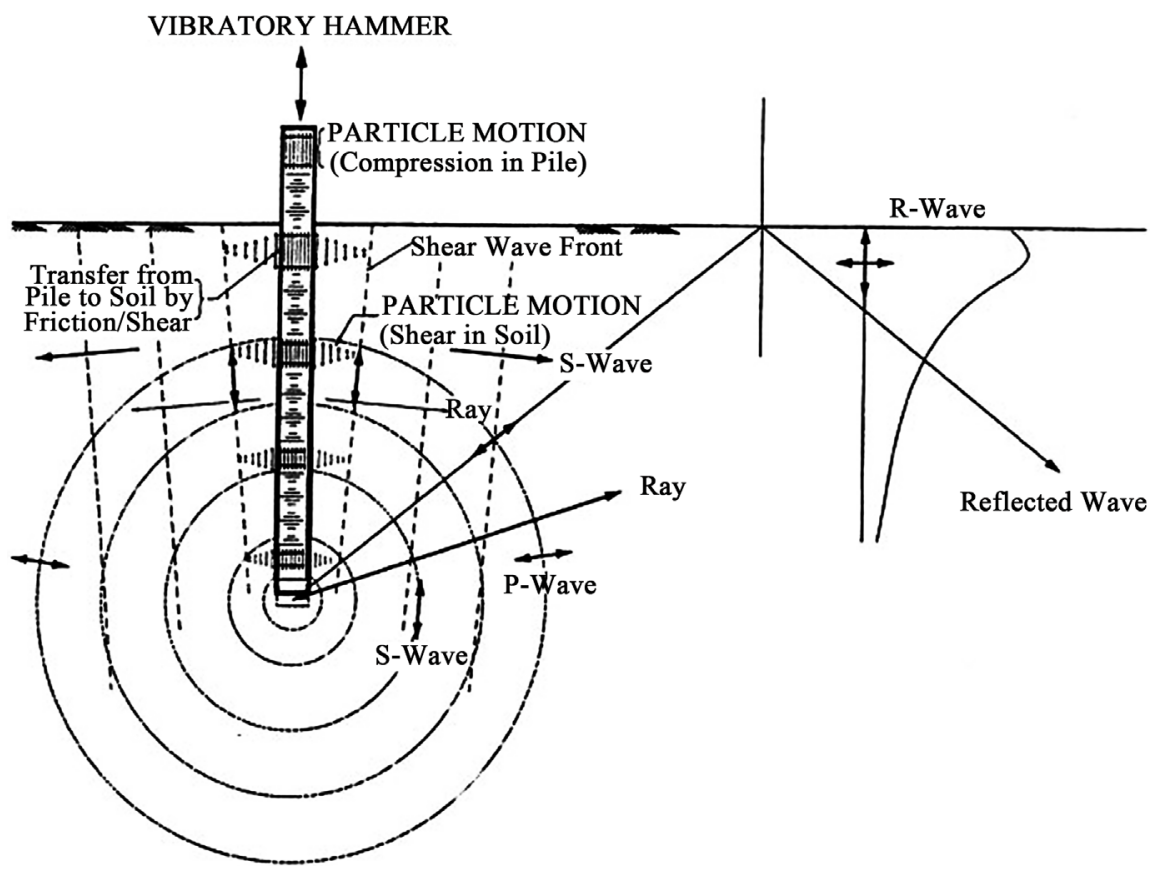

Figure 10. Generation mechanism of seismic waves during vibratory (or impact) driving of piles in homogeneous soil (adapted from Woods [11]). 


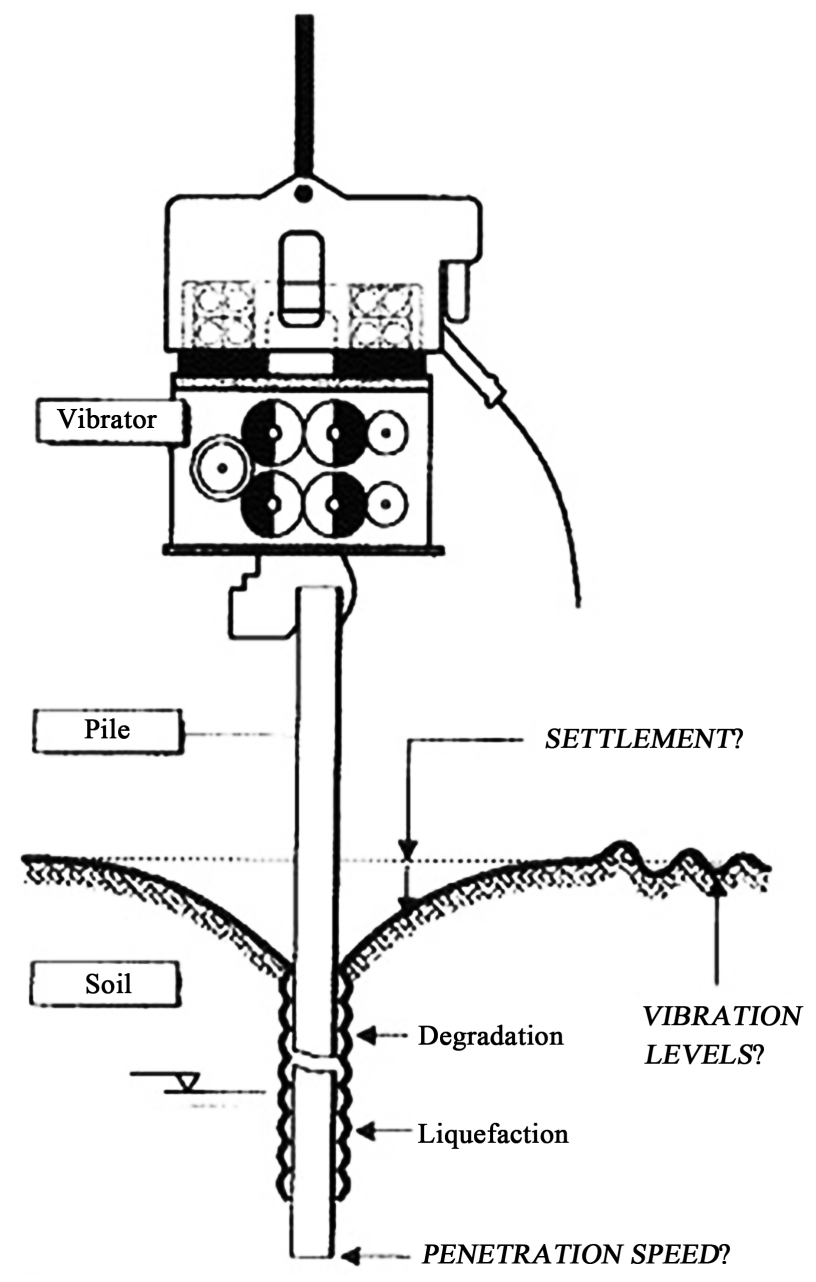

Figure 11. Issues concerning vibratory driving [12].

They influence the vibration levels, sheet pile installation rate, soil settlement [13] and, to a smaller extent, the noise.

With respect to the vibrating hammer (2), the most important properties are i.a. machine operating frequency, static-surcharge force (bias mass for the free-hanging system) and eccentric moment [1]. During the research presented in this article, a ICE 28 RF type vibratin hammer was used, of which the parameters are described in Section 5.

Regarding the sheet pile to be driven, the important factors are its geometry and frictional resistance of the sheet pile clutches. The difference in the appearance between severely used and new sheet pile clutches is shown in Figure 9.

Steel sheet piles are referred to as low-displacement piles. Here toe and lateral surface areas are important. A sheet pile with a larger cross-section moves a larger volume of soil, so its impact on the soil is larger than of a sheet pile with a smaller cross-section. Two types of sheet piles, i.e. GU20N and GU16-400, are described in more detail in Sections 2 and 6. The shearing force generated at the pile clutches has adverse influence on the vibration levels. 
During the sheet pile driving operation, it is possible for the sheet pile clutches to become jammed, which causes the sheet pile being driven to pull the sheet pile that has been driven. A similar situation may occur during the sheet pile extracting operation. If the sheet pile clutches are in a poor condition, the vibration amplitude value at the soil surface may increase by as much as $100 \%$ [1], which is shown in Figure 12. That situation occurred while driving the sheet pile S1, which in the middle of the installation $(6 \mathrm{~m})$ began pulling the adjacent sheet pile (G1). In effect, it was necessary to pull up the sheet pile G1, level it with the sheet pile S1 and drive them as a pair. At the same time, it should be added that the resistance occurring at the sheet pile clutches diminishes significantly on non-cohesive, but waterlogged soils [14].

In some cases, when the vibration measurement is exactly opposite, i.e. the vibration levels are higher for the sheet piles driven in pairs than for individual sheet piles. Such cases also occurred during the research described in this article. Nonetheless, this is an exceptional case. The G1 and G62_1 sheet piles were driven individually, while all other were driven on the previously driven sheet pile clutch.

With regard to the soil conditions (3) during the sheet pile vibratory driving, there are three types of resistance. The resistance under the sheet pile toe, at its lateral surface and at the pile sheet clutch are distinguished. Regardless of the vibrator (1) or sheet pile type (2), the soil conditions have the most influence on vibration levels. First of all it is important whether the soils are cohesive or non-cohesive. In non-cohesive soils, saturation is a crucial factor. In other
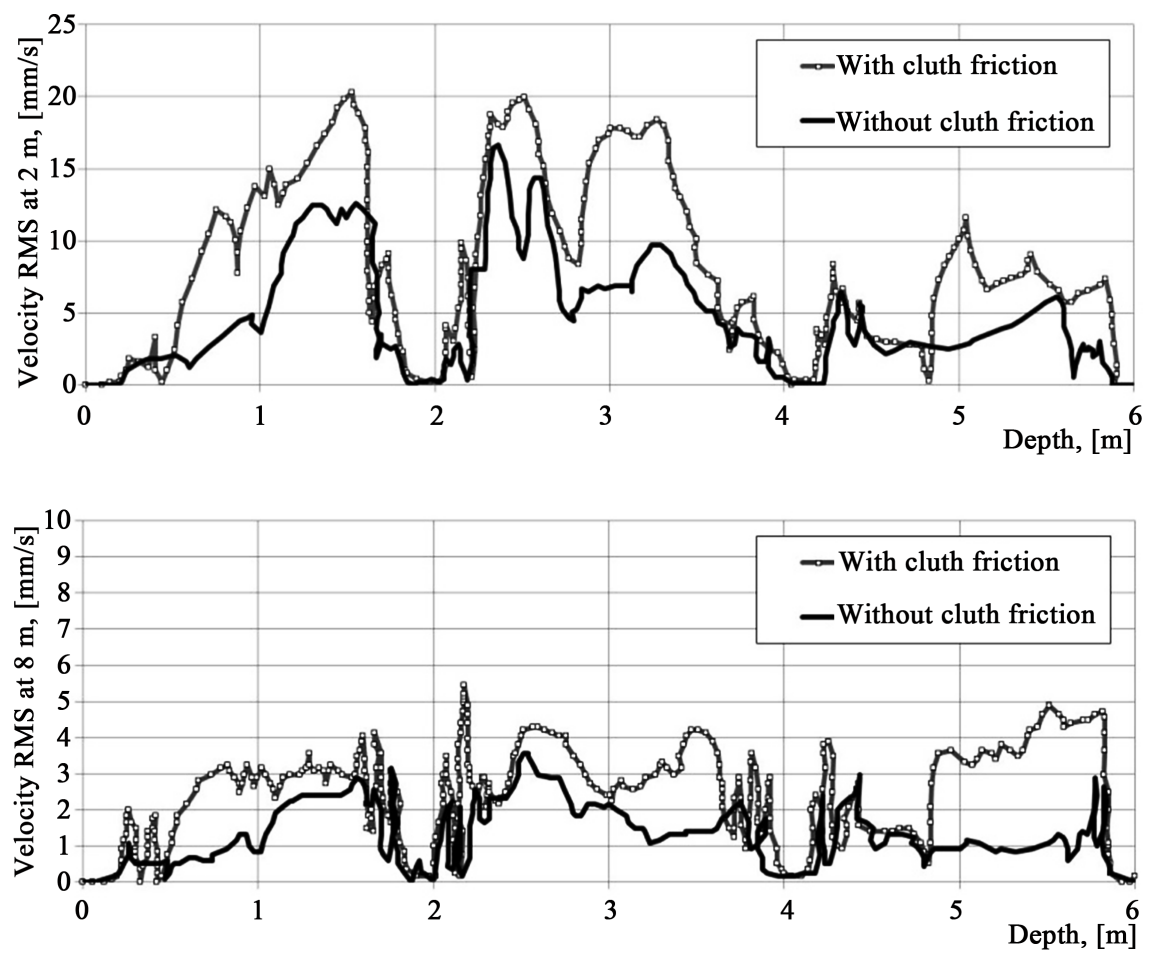

Figure 12. Comparisons of generated soil vibrations at two different radial distances, with and without presence of interlock frictions [1] after Legrand [15]. 
words, the level of ground waters presence matters. Another important factor are the soil grain size and diversity, therefore its capacity or incapacity of compaction (Figure 13). At the first stage of sheet pile vibratory driving, clutch and lateral surface resistance are negligible. Only the resistance under the sheet pile toe is important. This is one of the reasons behind the results that indicate better results of vibration reduction during jet-assisted sheet pile driving at the initial stage of the operation (Figure 17, Table 2(a) and Table 2(b)). During the sheet pile driving operation, the resistance at the lateral surface and at the clutch is increasing, while the resistance under the toe is losing its significance. While driving long sheet piles, at some point the resistance under the sheet pile toe has relatively small significance in comparison to the lateral surface and clutch resistance.

\section{Fieldwork}

\section{Instrumentation and equipment used for vibration measurements}

Three different types of sensors, the so-called geophones, were used to perform measurements. The measurements were taken using:

- two VIBRA geophones, manufactured by Profound BV, with the sampling frequency of $1024 \mathrm{~Hz}$, marked as ZRI and PPI in Figures 7(a)-(c).

- one Minimate Pro4 geophone with linear microphone, manufactured by Instantel, with the sampling frequency of $2048 \mathrm{~Hz}$, marked as JR in Figures $7(\mathrm{a})-(\mathrm{c})$.

All geophones are three-channel sensors that measure signals in the directions $\mathrm{x}, \mathrm{y}, \mathrm{x}$, where:

$X$ is the longitudinal direction (radial, perpendicular),

$Y$ is the diagonal direction (parallel),

$Z$ is the vertical direction, as shown in Figure 6.

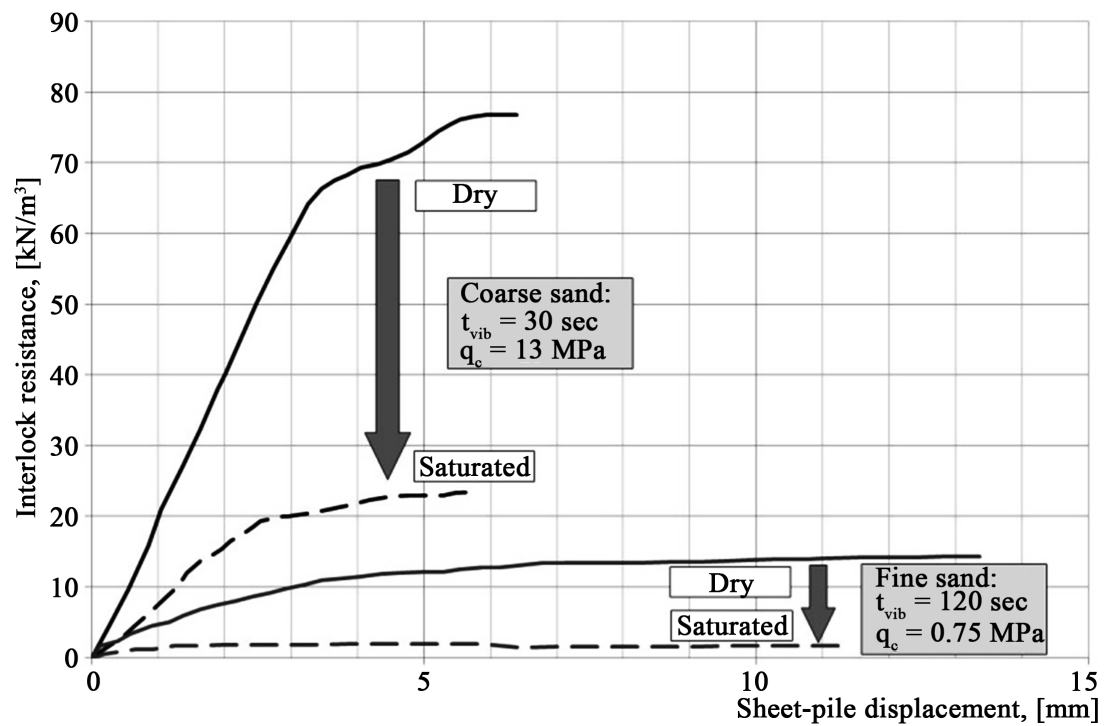

Figure 13. Results of the comparison of quasi-static, extraction, interlock resistance in saturated and dry sands (Vanden Berghe et al., 2001) [14]. 
Tables 2. Summarise the maximum and average of maximum values in every direction and at every distance with additional separation of values that occurred during the first 4 meters of sheet pile driving. (a) complete measurement to the full depth; (b) the first 4 meters of sheet pile driving.

(a)

\begin{tabular}{|c|c|c|c|c|c|c|c|c|c|c|c|}
\hline \multirow{3}{*}{ Sheet pile } & \multirow{2}{*}{$\begin{array}{c}\text { Direction } \\
\text { Distance }[\mathrm{m}]\end{array}$} & \multicolumn{3}{|c|}{$\mathrm{X}$} & \multicolumn{3}{|c|}{$\mathrm{Y}$} & \multicolumn{3}{|c|}{$\mathrm{Z}$} & \multirow{3}{*}{$\begin{array}{c}\text { Time } \\
\text { [min:sek }]\end{array}$} \\
\hline & & 5 & 10 & 15 & 5 & 10 & 15 & 5 & 10 & 15 & \\
\hline & Amplitude & & & & & & & & & & \\
\hline \multirow{3}{*}{ G1 } & $\mathrm{A}_{\max }$ & 9.056 & 5.56 & 6.06 & 8.11 & 2.03 & 2.35 & 9.99 & 3.78 & 4.47 & \multirow{3}{*}{ 01:52 } \\
\hline & $\mathrm{A}_{\mathrm{av}}$ & 6.16 & 3.79 & 3.35 & 5.36 & 1.42 & 1.83 & 6.56 & 2.83 & 3.1 & \\
\hline & $A_{\text {sum }}$ & 690 & 424 & 375 & 600 & 159 & 205 & 735 & 317 & 347 & \\
\hline \multirow{3}{*}{ G2 } & $A_{\max }$ & 11.32 & 3.94 & 8.41 & 11.66 & 3.11 & 6.89 & 11.53 & 5.95 & 7.58 & \multirow{3}{*}{ 04:14 } \\
\hline & $\mathrm{A}_{\mathrm{av}}$ & 6.05 & 1.91 & 5.11 & 6.99 & 1.93 & 3.54 & 7.06 & 2.95 & 4.42 & \\
\hline & $A_{\text {sum }}$ & 1538 & 485 & 1299 & 1776 & 489 & 900 & 1794 & 750 & 1123 & \\
\hline \multirow{3}{*}{ G3 } & $\mathrm{A}_{\max }$ & 7.361 & 7.94 & 8.11 & 13.52 & 3.65 & 7.95 & 12.29 & 5.22 & 8.56 & \multirow{3}{*}{ 04:42 } \\
\hline & $A_{a v}$ & 4.56 & 2.7 & 5.23 & 8.8 & 1.98 & 3.99 & 9.65 & 3.29 & 6.99 & \\
\hline & $A_{\text {sum }}$ & 1286 & 762 & 1475 & 2482 & 557 & 1125 & 2722 & 928 & 1971 & \\
\hline \multirow{3}{*}{ G4 } & $A_{\max }$ & 4.932 & 6.77 & 8.11 & 19.95 & 2.77 & 6.06 & 12.27 & 5.53 & 9.02 & \multirow{3}{*}{ 03:01 } \\
\hline & $\mathrm{A}_{\mathrm{av}}$ & 2.85 & 3.38 & 4.65 & 12.16 & 1.85 & 3.93 & 8.34 & 3.69 & 6.61 & \\
\hline & $A_{\text {sum }}$ & 516 & 612 & 843 & 2201 & 335 & 711 & 1509 & 667 & 1197 & \\
\hline \multirow{3}{*}{ G5 } & $A_{\max }$ & 8.282 & 3.63 & 5.83 & 15.84 & 2.38 & 7.42 & 10.83 & 3.98 & 8.18 & \multirow{3}{*}{$02: 33$} \\
\hline & $\mathrm{A}_{\mathrm{av}}$ & 2.87 & 2.1 & 2.76 & 9.96 & 1.52 & 2.76 & 9.03 & 2.35 & 5.62 & \\
\hline & $A_{\text {sum }}$ & 438 & 321 & 422 & 1524 & 232 & 423 & 1381 & 360 & 860 & \\
\hline \multirow{3}{*}{ S1 } & $A_{\max }$ & 6.132 & 5.23 & 8.41 & 12.11 & 2.61 & 4.77 & 10.9 & 5.37 & 9.47 & \multirow{3}{*}{$02: 23$} \\
\hline & $\mathrm{A}_{\mathrm{av}}$ & 3.56 & 2.36 & 3.54 & 6.71 & 1.45 & 2.15 & 7.06 & 3 & 4.4 & \\
\hline & $A_{\text {sum }}$ & 509 & 338 & 506 & 959 & 208 & 307 & 1009 & 428 & 629 & \\
\hline \multirow{3}{*}{ S2 } & $\mathrm{A}_{\max }$ & 7.842 & 3.04 & 5.91 & 17.96 & 3.36 & 6.89 & 13.94 & 4.49 & 7.88 & \multirow{3}{*}{$02: 55$} \\
\hline & $\mathrm{A}_{\mathrm{av}}$ & 5.68 & 2.38 & 4.39 & 12.12 & 1.89 & 4.44 & 9.64 & 2.69 & 6.31 & \\
\hline & $A_{\text {sum }}$ & 995 & 416 & 768 & 2119 & 331 & 777 & 1686 & 470 & 1104 & \\
\hline \multirow{3}{*}{ S3 } & $A_{\max }$ & 6.083 & 3.97 & 6.59 & 10.31 & 2.95 & 5.23 & 11.1 & 4.26 & 8.11 & \multirow{3}{*}{$02: 23$} \\
\hline & $\mathrm{A}_{\mathrm{av}}$ & 3.38 & 2.12 & 4.02 & 6.6 & 1.61 & 2.74 & 8.68 & 2.19 & 6.02 & \\
\hline & $A_{\text {sum }}$ & 483 & 303 & 575 & 944 & 230 & 392 & 1241 & 313 & 861 & \\
\hline \multirow{3}{*}{ S4 } & $A_{\max }$ & 2.747 & 2.59 & 1.67 & 10.9 & 1.8 & 3.11 & 10.62 & 4.51 & 5.23 & \multirow{3}{*}{$01: 42$} \\
\hline & $\mathrm{A}_{\mathrm{av}}$ & 2.06 & 1.39 & 1.03 & 7.57 & 1.27 & 2.12 & 8.04 & 2.31 & 3.15 & \\
\hline & $A_{\text {sum }}$ & 211 & 142 & 105 & 772 & 130 & 216 & 820 & 236 & 322 & \\
\hline & $A_{\max }$ & 5.497 & 3.96 & 3.94 & 12.96 & 2.52 & 4.62 & 12.78 & 2.96 & 8.11 & \\
\hline G62-1 & $\mathrm{A}_{\mathrm{av}}$ & 3.43 & 1.35 & 1.59 & 7.35 & 1.61 & 2.34 & 8.87 & 1.87 & 4.99 & 01:56 \\
\hline & $A_{\text {sum }}$ & 398 & 156 & 185 & 853 & 187 & 271 & 1029 & 217 & 579 & \\
\hline & $\mathrm{A}_{\max }$ & 6.261 & 3.45 & 6.36 & 17 & 2.3 & 6.82 & 16.42 & 4.07 & 10.76 & \\
\hline G62-2 & $A_{a v}$ & 4.59 & 2.61 & 5.28 & 11.57 & 1.86 & 5.09 & 11.84 & 2.61 & 7.76 & $03: 27$ \\
\hline & $A_{\text {sum }}$ & 950 & 540 & 1093 & 2395 & 385 & 1055 & 2452 & 540 & 1607 & \\
\hline & $A_{\max }$ & 8.438 & 5.89 & 7.2 & 15.45 & 4.69 & 10.15 & 14.72 & 5.04 & 10.91 & \\
\hline G62-3-4 & $\mathrm{A}_{\mathrm{av}}$ & 6.46 & 4.25 & 6.4 & 10.72 & 3.29 & 6.73 & 12.82 & 4.09 & 8.72 & 02:05 \\
\hline & $A_{\text {sum }}$ & 807 & 531 & 800 & 1339 & 412 & 841 & 1603 & 511 & 1091 & \\
\hline
\end{tabular}


(b)

\begin{tabular}{|c|c|c|c|c|c|c|c|c|c|c|}
\hline \multirow{3}{*}{ Sheet pile } & \multirow{2}{*}{$\begin{array}{c}\text { Direction } \\
\text { Distance }[\mathrm{m}]\end{array}$} & \multicolumn{3}{|c|}{$\mathrm{X}$} & \multicolumn{3}{|c|}{$\mathrm{Y}$} & \multicolumn{3}{|c|}{ Z } \\
\hline & & 5 & 10 & 15 & 5 & 10 & 15 & 5 & 10 & 15 \\
\hline & Amplitude & & & & & & & & & \\
\hline \multirow{3}{*}{ G1 } & $\mathrm{A}_{\max }$ & 7.256 & 5.56 & 6.06 & 7.899 & 1.8 & 1.97 & 9.99 & 3.78 & 4.47 \\
\hline & $\mathrm{A}_{\mathrm{av}}$ & 4.28 & 3.13 & 2.05 & 4.92 & 1.18 & 1.1 & 5.34 & 2.61 & 2.46 \\
\hline & $A_{\text {sum }}$ & 150 & 109 & 72 & 172 & 41 & 39 & 187 & 91 & 86 \\
\hline \multirow{3}{*}{ G2 } & $A_{\max }$ & 9.23 & 3.1 & 7.8 & 9.18 & 2.66 & 3.94 & 9.68 & 5.95 & 4.55 \\
\hline & $\mathrm{A}_{\mathrm{av}}$ & 5.83 & 1.55 & 4.56 & 7.19 & 1.79 & 2.83 & 6.93 & 2.84 & 3.81 \\
\hline & $A_{\text {sum }}$ & 653 & 174 & 510 & 805 & 201 & 317 & 776 & 318 & 427 \\
\hline \multirow{3}{*}{ G3 } & $A_{\max }$ & 4.118 & 2.2 & 5.15 & 13.52 & 3.65 & 4.85 & 11.68 & 4.56 & 8.56 \\
\hline & $\mathrm{A}_{\mathrm{av}}$ & 3.13 & 1.54 & 3.4 & 10.73 & 2.74 & 2.65 & 9.56 & 3.65 & 6.46 \\
\hline & $A_{\text {sum }}$ & 313 & 154 & 340 & 1072 & 274 & 265 & 956 & 365 & 646 \\
\hline \multirow{3}{*}{ G4 } & $A_{\max }$ & 3.855 & 3.21 & 5.61 & 19.95 & 2.73 & 5.45 & 12.27 & 5.53 & 8.11 \\
\hline & $\mathrm{A}_{\mathrm{av}}$ & 2.64 & 2.78 & 4.79 & 17.61 & 2.39 & 4.28 & 10.52 & 4.24 & 7.04 \\
\hline & $A_{\text {sum }}$ & 213 & 226 & 388 & 1426 & 194 & 347 & 851 & 343 & 570 \\
\hline \multirow{3}{*}{ G5 } & $\mathrm{A}_{\max }$ & 8.282 & 3.34 & 5.83 & 15.84 & 2.12 & 7.42 & 10.83 & 3.98 & 7.35 \\
\hline & $\mathrm{A}_{\mathrm{av}}$ & 3.66 & 1.93 & 2.76 & 12.52 & 1.76 & 3.48 & 9.44 & 3.23 & 5.52 \\
\hline & $A_{\text {sum }}$ & 190 & 100 & 143 & 651 & 91 & 181 & 491 & 168 & 287 \\
\hline \multirow{3}{*}{ S1 } & $\mathrm{A}_{\max }$ & 3.66 & 1.81 & 2.88 & 7.45 & 1.59 & 3.03 & 9.16 & 2.51 & 6.14 \\
\hline & $\mathrm{A}_{\mathrm{av}}$ & 3.07 & 1.53 & 1.34 & 5.47 & 1.08 & 1.77 & 6.45 & 1.96 & 2.72 \\
\hline & $\mathrm{A}_{\text {sum }}$ & 212 & 106 & 92 & 377 & 74.7 & 122 & 445 & 135 & 187 \\
\hline \multirow{3}{*}{ S2 } & $A_{\max }$ & 6.91 & 3.04 & 5.45 & 16.23 & 3.36 & 6.82 & 11.31 & 3.33 & 7.27 \\
\hline & $\mathrm{A}_{\mathrm{av}}$ & 4.02 & 1.85 & 2.4 & 11.1 & 1.84 & 3.58 & 8.4 & 2.25 & 4.69 \\
\hline & $A_{\text {sum }}$ & 245 & 113 & 146 & 677 & 112 & 218 & 512 & 137 & 286 \\
\hline \multirow{3}{*}{ S3 } & $A_{\max }$ & 4.131 & 2.61 & 6.59 & 10.31 & 1.76 & 5.23 & 11.076 & 2.39 & 8.11 \\
\hline & $\mathrm{A}_{\mathrm{av}}$ & 3.2 & 1.56 & 3.59 & 8.24 & 1.29 & 2.99 & 8.64 & 1.59 & 5.31 \\
\hline & $A_{\text {sum }}$ & 192 & 93 & 215 & 495 & 77 & 179 & 518 & 95 & 319 \\
\hline \multirow{3}{*}{ S4 } & $\mathrm{A}_{\max }$ & 2.299 & 1.4 & 1.67 & 6.625 & 1.56 & 2.35 & 7.766 & 2.98 & 4.47 \\
\hline & $A_{a v}$ & 1.72 & 1.1 & 0.89 & 4.82 & 0.98 & 1.62 & 5.86 & 1.89 & 2.29 \\
\hline & $A_{\text {sum }}$ & 65 & 42 & 34 & 183 & 37 & 61 & 223 & 72 & 87 \\
\hline \multirow{3}{*}{ G62-1 } & $\mathrm{A}_{\max }$ & 5.497 & 1.34 & 3.03 & 8.618 & 2.15 & 4.24 & 9.871 & 2.96 & 6.89 \\
\hline & $\mathrm{A}_{\mathrm{av}}$ & 4.23 & 1.12 & 1.64 & 7.24 & 1.77 & 2.59 & 9.16 & 2.07 & 5.3 \\
\hline & $A_{\text {sum }}$ & 224 & 60 & 87 & 384 & 94 & 137 & 486 & 110 & 281 \\
\hline \multirow{3}{*}{ G62-2 } & $\mathrm{A}_{\max }$ & 4.868 & 3.45 & 6.21 & 16.17 & 2.3 & 6.82 & 13.72 & 2.97 & 9.17 \\
\hline & $\mathrm{A}_{\mathrm{av}}$ & 4.26 & 2.37 & 4.47 & 12 & 1.84 & 4.24 & 10.93 & 1.94 & 7.1 \\
\hline & $A_{\text {sum }}$ & 332 & 185 & 349 & 936 & 144 & 330 & 853 & 152 & 554 \\
\hline \multirow{3}{*}{ G62-3-4 } & $\mathrm{A}_{\max }$ & 8.155 & 4.1 & 7.12 & 15.45 & 3.94 & 10.15 & 14.72 & 4.24 & 10.91 \\
\hline & $\mathrm{A}_{\mathrm{av}}$ & 5.99 & 3.68 & 6.31 & 11.13 & 3.53 & 7.8 & 12.76 & 3.69 & 8.95 \\
\hline & $A_{\text {sum }}$ & 407 & 250 & 429 & 757 & 240 & 530 & 868 & 251 & 609 \\
\hline
\end{tabular}


All directions, i.e. $\mathrm{X}, \mathrm{Y}, \mathrm{Z}$, are perpendicular to one another.

The memory of these sensors registers, by means of a portable computer, the maximum vibration velocity (PPV) values larger than $0.1 \mathrm{~mm} / \mathrm{s}$ and stores the highest value within the 10 second interval. The geophone located at the distance of $5 \mathrm{~m}$ from the vibration source was configured with a one-second interval. A continuous line was drawn between the measurement points in the 10-second interval and 1-second interval plots. This resulted in a plot closed by the vibration value (PPV) axis, the sheet pile depth axis and the line drawn between the points. Based on the Authors own research presented in this article, the plot surface area for the device with a 1-second interval covers $87 \%$ of the plot surface area for the device with a 10 -second interval, which is shown in Figure 14.

The Minimate Pro4 geophone, marked as JR, registered also the noise level during the sheet pile driving operation in decibels $[\mathrm{dB}]$ using butli-in noise and anti-aliasing filters. It was located at the distance of $10 \mathrm{~m}$ from the vibration source. This device had been used for similar measurements before [16]. Furthermore, a video camera was used to record the sheet pile driving operation. The purpose of the video camera was to support the geophone measurement

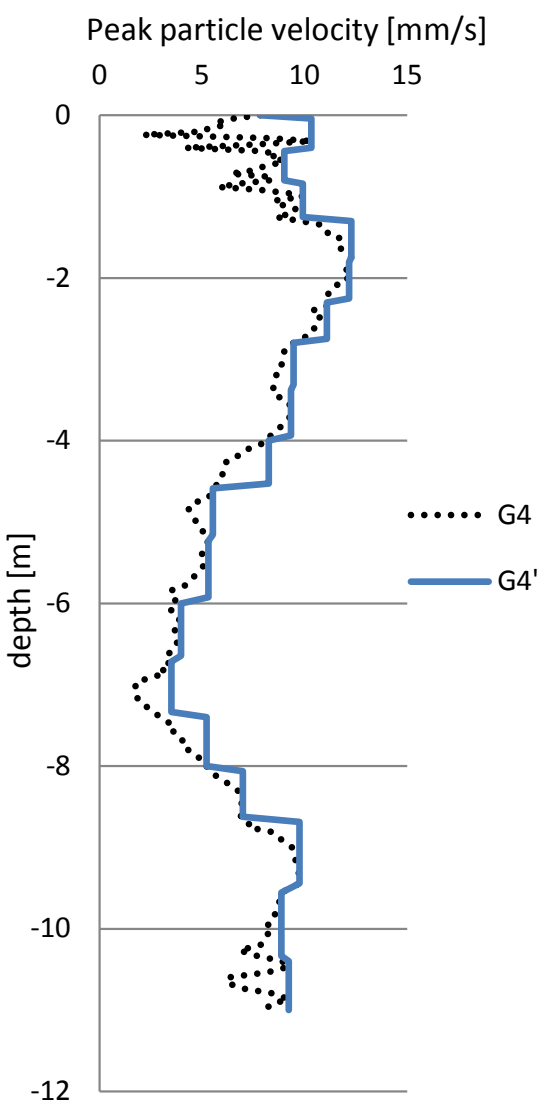

(a)

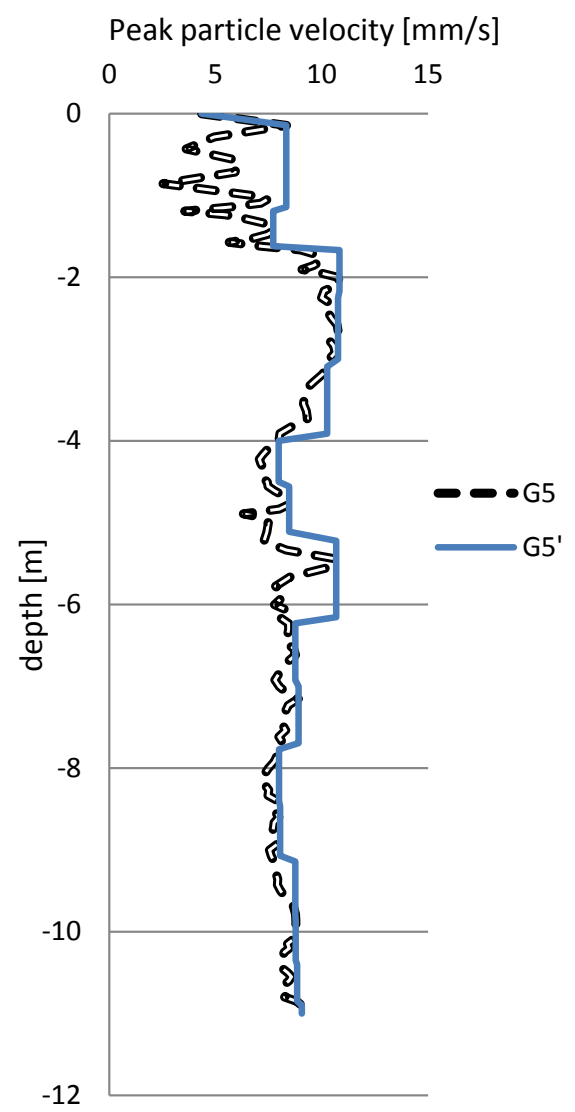

(b)

Figure 14. Plots of peak particle velocity vs depth of G4 and G5 sheet piles measured at the distance of $5 \mathrm{~m}$ in Z-vertical direction. G4 and G5 are measured with a 1-second interval, and G4', G5' are measured with a 10-second interval. 
results. The recordings allowed to estimate the sheet pile driving rate. Besides it was possible to determine, whether at the given moment the sheet pile was being driven or extracted, and whether the sheet pile being driven did not pull the previously driven sheet pile into the soil. Before driving, the sheet piles were marked with paint every $1 \mathrm{~m}$. Thus, it was possible to determine the location of the sheet pile toe in the soil, which allowed data comparison with the resulting vibration velocity. In the end, it was possible to draw a plot with the PPV value and the sheet pile toe depth as axes.

The VIBRA geophones (marked as ZRI and PPI) were installed on a steel support with the weight of $10.9 \mathrm{~kg}$. The Minimate Pro4 geophone was also installed on a slightly smaller plate, pressed into the soil on 3 thin, $10 \mathrm{~cm}$ long rods. Each geophone was covered with a $25 \mathrm{~kg}$ sandbag to protect the sensors from noise and to obtain additional weight on the soil. The total weight of a steel support and a sandbag was approx. $36 \mathrm{~kg}$.

\section{Equipment Used for Sheet Piling}

For the purposes of this study a ICE 28 RF (Resonance Free) free-hanging vibrating hammer was used. The vibrating hammer operating frequency was 2300 rpm, which is equivalent to $38.3 \mathrm{~Hz}$. The vibrating hammer weight was $7100 \mathrm{~kg}$ and its eccentric moment is $28 \mathrm{kgm}$. This vibrating hammer had been selected based on soil conditions, e.g. compacted sands. Furthermore, at present this type of vibrating hammers are commonly used in the European markets, especially in urban areas. To perform the jet-assisted sheet pile driving operation, a high pressure pump was used. The driven sheet piles were new GU20N type and severely used GU16-400 type. Only GU20N sheet piles were used for the jet-assisted sheet pile driving. The sheet piles installed through jet-assisted driving were marked as S1, S2, S3 and S4. The others were marked as G1, G2 etc. For more details on sheet piles, see Table 1.

\section{Profiles}

Two types of sheet piles were used. The new GU20N and the used GU16-400. All of them had been manufactured by Arcelor Mittal in Poland as hot-rolled profiles. GU20N is a new product, manufactured in Poland after the merger of Arcelor and Mittal Steel. In Europe this profile is known as PU18 [17]. The GU16-400 is a legacy-type sheet pile, which is very common in Poland, because in the past it was a profile manufactured by Polish steelworks under the name of G62 (based on of the 1 meter sheet pile weight of $62 \mathrm{~kg}$ ). The GU16-400 has poor endurance properties in relation to its weight, in particular with respect to static properties of excavation shoring. This is especially visible in comparison to the modern U-type profile. On the other hand, this sheet pile is much more durable for repeated use, e.g. as temporary protection [18].

\section{Geological Conditions}

The measurements had been taken in October 2013, in Bojszowy Nowe (Śląskie 
Voivodeship, Poland). The soil conditions are known based on the geotechnical calculations performed in 2006-2008 for the purposes of the analysis of jet grouting columns co-operation with the subsurface [19]. Additionally, in November 2013 one control borehole was made, mainly for the purposes of ground water level verification, which was found at $3.4 \mathrm{~m}$ below the ground level (previously, the ground water level had been determined at $1.8-2.3 \mathrm{~m}$ below the ground level) [19]. The dominant soils are non-cohesive Quaternary deposits, including fine sands and sandy gravel. An example geological hole with selected soil parameters and the modulus of compression variation distribution (M) with depth, determined using a DMT-type probe, are shown in Figure 15(a) and Figure 15(b). More over results of CPTu test are shown in Figure 15(c) and Figure 15(d).

The higher modulus of compression (M) directly below the soil level is connected with the steel pipes being stored in the area before geological examination, which increased the weight on this soil surface. During the research related to sheet pile driving, the pipes were no longer there and therefore the modulus values in Figure 15(b) are higher than they actually were.

\section{Results}

The research results reported in this section were obtained during the sheer pile driving operations in Bojszowy Nowe, Southern Poland. The basic results relate to the scope of:

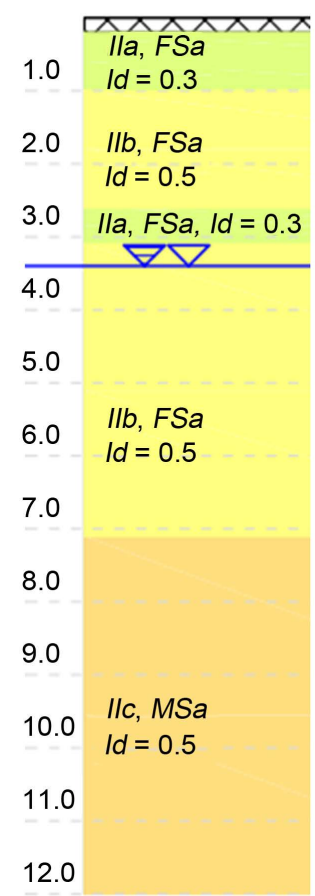

(a)

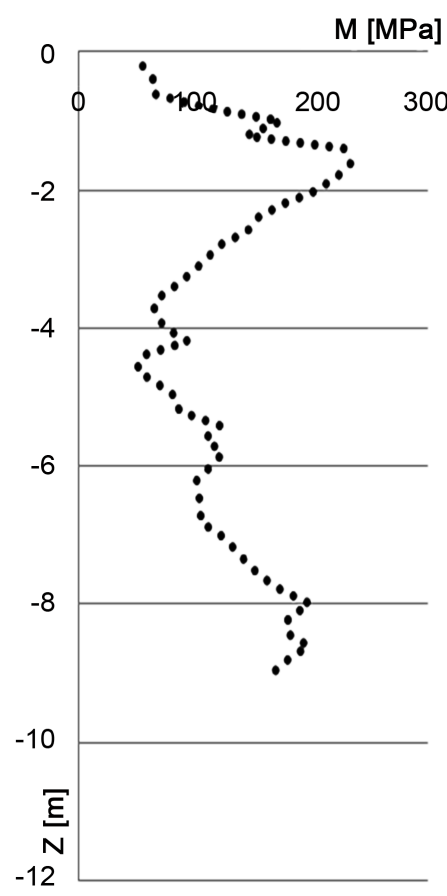

(b)

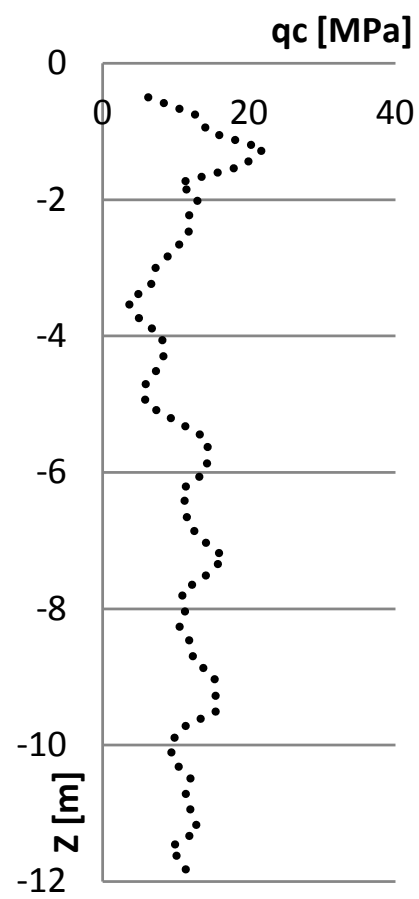

(c)

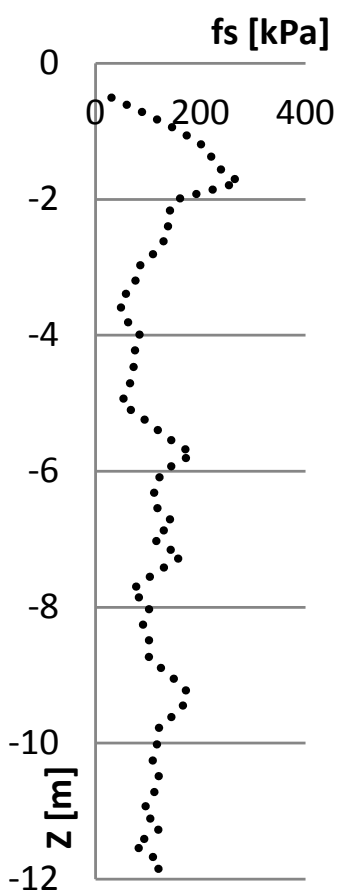

(d)

Figure 15. Geological conditions: (a) cross section with water Table level and density index of ground layers; (b) modulus of compression variation distribution with depth $(\mathrm{DMT})$; (c) resistance of the cone $(\mathrm{CPTu})$; (d) sleeve resistance $(\mathrm{CPTu})$. 
1) vibration amplitudes

2) noise amplitudes

3) duration of these disturbances.

In the scope of vibration amplitude registration, a table summary (Table 2(a) and Table 2(b)) has been prepared, including:

- $A_{\max }-$ maximum amplitude values (PPV values) $[\mathrm{mm} / \mathrm{s}]$,

- $A_{a v}$-average amplitude values $[\mathrm{mm} / \mathrm{s}]$,

- $A_{\text {sum }}$-total amplitude value for the given sheet pile $[\mathrm{mm} / \mathrm{s}]$.

With regard to the standards that define allowable vibrations for structures, the most important parameter is the maximum amplitude. Nonetheless, in the opinion of the Authors, the average amplitude value and the total amplitude value are instrumental to a comprehensive analysis of results in order to answer the question, whether vibrations have been reduced and if so, to what extent.

The average amplitude value gives a more precise indication of the possible vibration reduction due to the fact that the maximum amplitude value may always be somewhat random. For example, a sheet pile can hit a local obstacle with impact on the PPV value, e.g. an underground rock. In that case, calculating the average value for the whole vibratory driving process levels such anomalies to some extent. Using the average value is even more justified, because the maximum PPV values measured at the soil surface cannot be related to the construction standards. It is impossible to perform two identical measurements during the sheet pile driving operation. Indicating the average amplitude value reduces, to some extent, the occurrence of extreme results.

On the other hand, the total amplitude value is important only because of perception of the vibration by people. It is the sum of maximum amplitude values during the period of time, in which they occurred. Hence, this value combines in itself the reduction of amplitude values and the reduction of time, in which they occur.

The results have been divided into two groups, depending on the sheet pile penetration depth:

1) 0 - $11 \mathrm{~m}$ below the ground level-see plots in Appendix A and Table 2(a),

2) 0 - $4 \mathrm{~m}$ below the ground level-see plots in Appendix B and Table 2(b).

This division was introduced because of ground water at $3.4 \mathrm{~m}$ below the ground level.

Furthermore, Table 2(a) and Table 2(b) contain the results in three directions $(\mathrm{X}, \mathrm{Y}, \mathrm{Z})$ and at each distance $(5 \mathrm{~m}, 10 \mathrm{~m}, 15 \mathrm{~m})$ for every sheet pile. Table 2(a) contains the results with regard to sheet pile penetration to the full depth, while Table 2(b) up to the depth of $4 \mathrm{~m}$. The table also includes data related to the time, in which each sheet pile was driven. Due to the amount of data included in the table and in order to present them more clearly and facilitate their interpretation, the Appendix A and Appendix B contain plots with maximum and average amplitudes for each sheet pile. The results presented in the form of plots have been prepared in the order of sheet piles driving. From the left side, it shows the results for the first sheet pile and then for the subsequent sheet piles 
up to the last one, for which the result is on the right side of the plot. It should be noted that the vibration frequency measured with geophones was $36-38 \mathrm{~Hz}$ for all sheet piles, throughout the research.

Due to the fact that the measurements were taken at the soil, their values should not be used to determine, whether the vibrations would have been allowable with regard to buildings. Only in the case of light structures can the vibration levels measured at the soil be similar to the levels measured at the structure. Still, even in such cases it is recommended to perform measurements at the structure and not at the soil.

On the other hand, the results may be related to the influence on people, e.g. to the people in the vicinity of the construction site (Figure 16).

Noise levels were measured at the distance of $10 \mathrm{~m}$ from the source. The frequency was in the range of $80-110 \mathrm{~Hz}$. The source of the noise, apart from the ICE $28 \mathrm{RF}$ vibrating hammer, was the equipment used for the vibrating hammer operation, including the wheeled crane with the lifting capacity of $40 \mathrm{t}$ and the power unit, located right next to the sheet pile driving point. The measurement was performed with an extremely unfavourable parallel equipment arrangement. The noise level was $119-122 \mathrm{~dB}$ for the sheet piles installed without jet-assisted driving, i.e.

G3: $123.7 \mathrm{~dB}$

G4: $122.7 \mathrm{~dB}$

G5: $120.3 \mathrm{~dB}$.

For the sheet piles installed using jet-assisted driving, the noise level was approx. $3 \mathrm{~dB}$ lower, i.e.:

S2: $119.6 \mathrm{~dB}$

S3: $119.5 \mathrm{~dB}$

S4: $117.5 \mathrm{~dB}$.

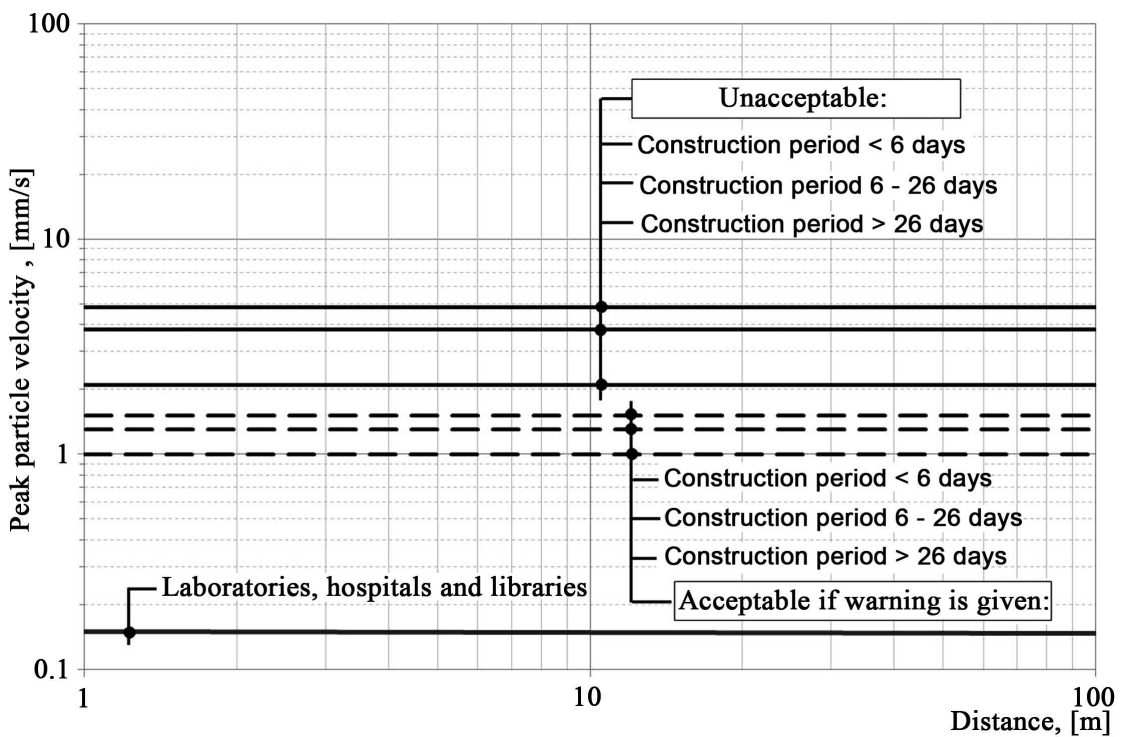

Figure 16. Maximum acceptable vibrations to prevent human disturbance-Eurocode 3 [9]. 
The difference of approx. $2.5 \%$ is not significant. Yet the $120 \mathrm{~dB}$ noise level is a dangerous threshold referred to as the pain threshold, which is dangerous to people because of the pain and the risk of permanent hearing loss.

Apart from the reduction of vibrations and an insignificant reduction of noise, the time required for pressure jet-assisted sheet pile driving was much shorter. The installation was from 40 to 180 seconds faster. Individually driven G1 and G62_1 sheet piles, for which the time was similar to the S4 using jet-assisted driving, were an exception.

The measurements at the soil surface resulted in points with a 1 or $10 \mathrm{~s}$ interval. In order to facilitate the interpretation of results, the points have been connected, which in itself is a simplification of results. The plots shown in Figure 17 and Figure 18 include the PPV values $[\mathrm{mm} / \mathrm{s}]$ related to the sheet pile toe level.
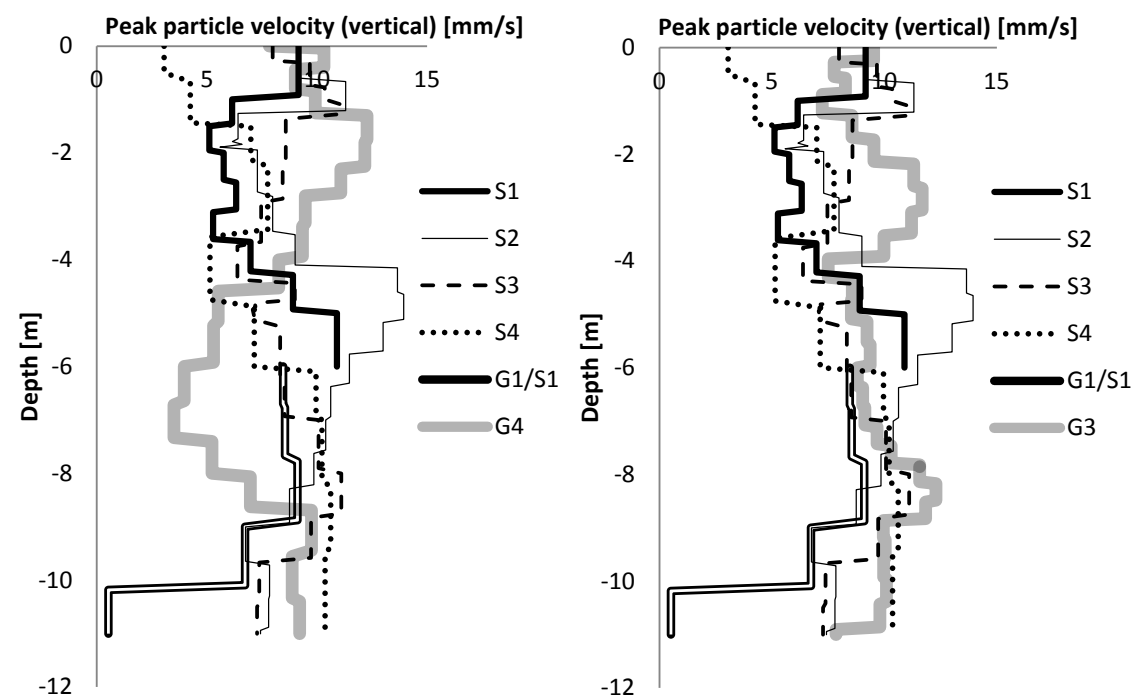

Figure 17. Comparison of S1 - S4 with G4 (on the left) and with G3 (on the right) sheet piles ( $\mathrm{Z}$ direction, $5 \mathrm{~m}$ ).

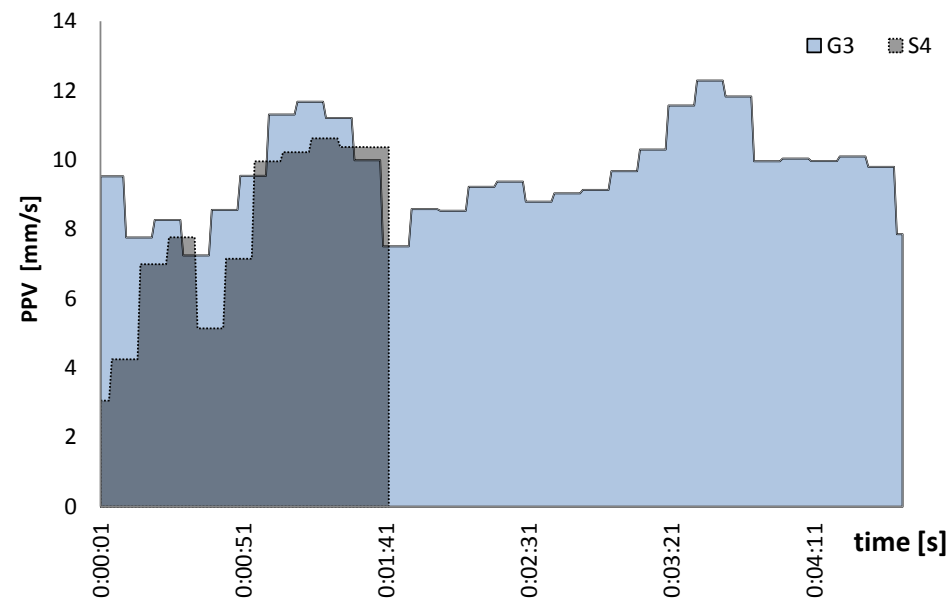

Figure 18. Comparison of G3 and S4 with G4 driveability on ppv vs time plot (X direction, $5 \mathrm{~m}$ ). 


\section{Numerical Analysis}

\section{Introduction. Creation of a model}

An attempt was made to obtain results similar to the in situ experimental plot in Bojszowy Nowe using finite element method FEM. For this purpose a version of Student program Z_Soil v11-with 4000 nodes limit [20]. The main task was to create a computational model that allows for the analysis of vibration velocity in the subsoil at any time and place.

Modeling of the ground and sheet pile the boundary and initial conditions

In a two dimensional plane strain the numerical model with dimensions of 30 $\mathrm{m}$ in the longitudinal direction $\mathrm{X}$ and $17 \mathrm{~m}$ in the vertical direction $\mathrm{Y}$ (in the previous section for the field trials, this direction is referred to as $\mathrm{Z}$ ) was created. Infinite elements used in both directions. As the boundary conditions assumed typical support to prevent the movement of soil in the $\mathrm{X}$ and $\mathrm{Y}$. The supports are located at the edges; at the edges of the vertical support in the horizontal direction only. Due to the use of finite element support also it is infinite. At $t=0$ the displacement and speed of all points are 0 . The method solves the problem of finite elements using a differential Equation (1):

$$
M \cdot u+C \cdot u+K \cdot u=P(t)
$$

where:

$u$-vector of displacements,

$M, C$ and $K$-matrix of mass, damping and stiffness,

$P(t)$-load matrix.

The model shown in Figure 19, and the parameters listed in Table 3. Elastic-perfectly plastic model of the surface Coulomb-Mohr was used. The mechanism of suppression, which has a decisive influence on the disappearance of vibrations in the substrate and directly affects the scope of impact shock, adopted as proposed by Rayleigh:

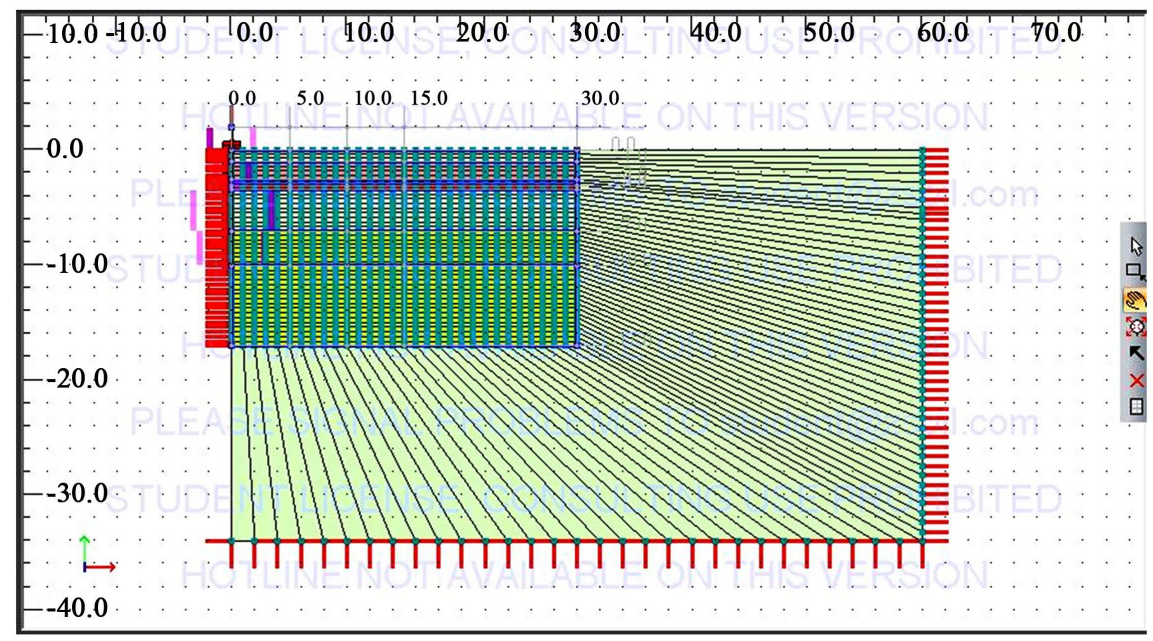

Figure 19. Sketch a model option I with 1471 nodes and $10 \mathrm{~cm}$ zone of contact between the sheet piling. 
Table 3. Parameters of elastic-perfectly plastic surface Coulomb-Mohr model.

\begin{tabular}{ccccccc}
\hline 1.p. & $\begin{array}{c}\text { Parameters } \\
\text { Layers of soil assumed to model }\end{array}$ & $\begin{array}{c}\text { Young modulus } \\
{[\mathrm{kPa}]}\end{array}$ & $\begin{array}{c}\varnothing \\
{[\mathrm{c}]}\end{array}$ & $\begin{array}{c}\mathrm{c} \\
{[\mathrm{kPa}]}\end{array}$ & $\begin{array}{c}\mathrm{H} \\
{[\mathrm{m}]}\end{array}$ & $\begin{array}{c}\Gamma \\
{\left[\mathrm{kN} / \mathrm{m}^{3}\right]}\end{array}$ \\
\hline 1 & IIa. FSa & 60,000 & 39 & 0 & 1.0 & 20 \\
2 & IIb, FSa & 80,000 & 35 & 0 & 1.5 & 20 \\
3 & IIa, Fsa & 60,000 & 35 & 0 & 0.5 & 20 \\
4 & IIb, FSa & 80,000 & 35 & 0 & 0.4 & 20 \\
5 & IIb, FSa & 80,000 & 35 & 0 & 3.6 & 10 \\
6 & IIc, MSa & 80,000 & 34 & 0 & 10 & 10 \\
7 & Infinite elements & 250,000 & - & - & - & - \\
\hline
\end{tabular}

$$
C=\alpha \cdot M+\beta \cdot K
$$

For Eupieziowiec [21] the size of $\alpha$ and $\beta$ are damping parameters. In the following analysis assumes that $\alpha=1.0 \mathrm{~s}^{-1}$ oraz $\beta=0.02 \mathrm{~s}$.

The level of ground water taken into account by reducing the weight of the volume of land of $10 \mathrm{kN} / \mathrm{m}^{3}$. Diagnosis ground conditions are, in effect the area to $12 \mathrm{~m}$ below ground level assumed continuity of the deepest layer to a depth of $17 \mathrm{~m}$ below ground level. At the edge of the model used elements of the infinite. They are designed to prevent wave reflection and limit the number of nodes in the model. Sheet pile in subsoil modeled as a steel section (key beam) having a predetermined cross-sectional area, moment of inertia, Young's modulus and Poisson's ratio as steel and who is a result of the weight of the weight difference of steel and ground.

After performing a number of different simulations accepted for presentation in this paper, two versions of the model differentiated by:

- the number of nodes,

- the scope of the contact zone.

\section{Load function}

The function of the load modeled as mass vibro hammer acting on the sheet piling with reversible action, i.e. with the sign "+" and "-" on the vertical axis. Forced displacement elements simulating introduced sheet piling into the ground is obtained by changing the sign 38 times per second, which corresponds to the frequency of vibration hammer of $38 \mathrm{~Hz}$.

\section{Contact modeling}

Simulation of contact in the early attempts included parameter changes the angle of internal friction $\varnothing$ and cohesion c. However, even assuming very different values within the function interface is not observed a significant impact of changes in these parameters on the results obtained. Due to the lack of knowledge about the process taking place in the ground contact sheet piling driven dynamically, both during water jet-assisted and without water jet-assisted assumes simplified consisting of:

- for piling without water jet-assisted assumed that the value of the parameters 
of the model parameters corresponds to the ground contact, which is a sheet pile,

- for water jet-assisted piling parameters $\varnothing$ and $\mathrm{c}$ are close to 0 (simulates a smooth glide).

Two models that are presented are different because of range the area around the water jet-assisted sheet pile, where soil parameters have deteriorated since the actual presented in Table 3, to values close to zero. In the first case (variant v1) applied little affected zone of $10 \mathrm{~cm}$. In the second (case v2) affected zone extends $100 \mathrm{~cm}$. Furthermore, as previously mentioned variants differ in the number of nodes that are the option I: 1471 and option II: 2936.

\section{Results}

The results are presented in the form of graphs comparing the graph water jet-assisted sheet piling S4_v1 or S4_v2 and without water jet-assisted G3_v1 or G3_v2 by Table 4. The values similar between the computational model and field measurements were obtained at a distance of $15 \mathrm{~m}$ from the place of vibration excitation. The results of the calculation model in distance of $5 \mathrm{~m}$ and $10 \mathrm{~m}$ of the excitation points were higher than the measured in field.

The results obtained in-situ at a distance of 15 meters from the source of vibration were very much in line with numerical simulations. The results at 5 and 10 meters in numerical analyzes are higher than those measured in-situ. This may result from the degradation of the soil stiffness at higher vibration amplitudes. In order to be able to include this in the analysis, a more complex constitutive model should be used in the analysis, which will be able to describe this type of non-linearity. This will be the subject of further research and analysis.

Figure 20 comprises a measurement in the horizontal direction $\mathrm{X}$ and vertical direction $\mathrm{Z}$ within $5 \mathrm{~m}, 10 \mathrm{~m}$ and $15 \mathrm{~m}$ to v1 calculation program $\mathrm{Z}$ _Soil. Figure 21 contains similar plots, but for v2 calculations in Z_Soil.

\section{Discussion of the results}

Based on the results obtained in the Z_Soil author makes the following conclusions:

The assumptions:

Table 4. Brief description of sheet piles and computational model.

\begin{tabular}{|c|c|}
\hline Sheet pile symbol & Explanation \\
\hline S4_v1 & $\begin{array}{l}\text { Prefabricated pile toe as a hole with a diameter of } 20[\mathrm{~mm}](\text { Table } 1) . \\
\text { The calculation model v1, the impact zone-10 [cm]; number of nodes } 1471\end{array}$ \\
\hline S4_v2 & $\begin{array}{l}\text { Prefabricated pile toe as a hole with a diameter of } 20[\mathrm{~mm}] \text { (Table } 1) \text {. } \\
\text { The calculation model v2, the impact zone-100 [cm]; number of nodes-2936 }\end{array}$ \\
\hline G3_v1 & $\begin{array}{l}\text { Ordinary sheet piles-without water jet-assisted (Table } 1) \text {. } \\
\text { The calculation model v1, the impact zone-10 [cm]; number of nodes } 1471\end{array}$ \\
\hline G3_v2 & $\begin{array}{l}\text { Ordinary sheet piles-without water jet-assisted (Table } 1 \text { ). } \\
\text { The calculation model v2, the impact zone-100 [cm]; number of nodes-2936 }\end{array}$ \\
\hline
\end{tabular}



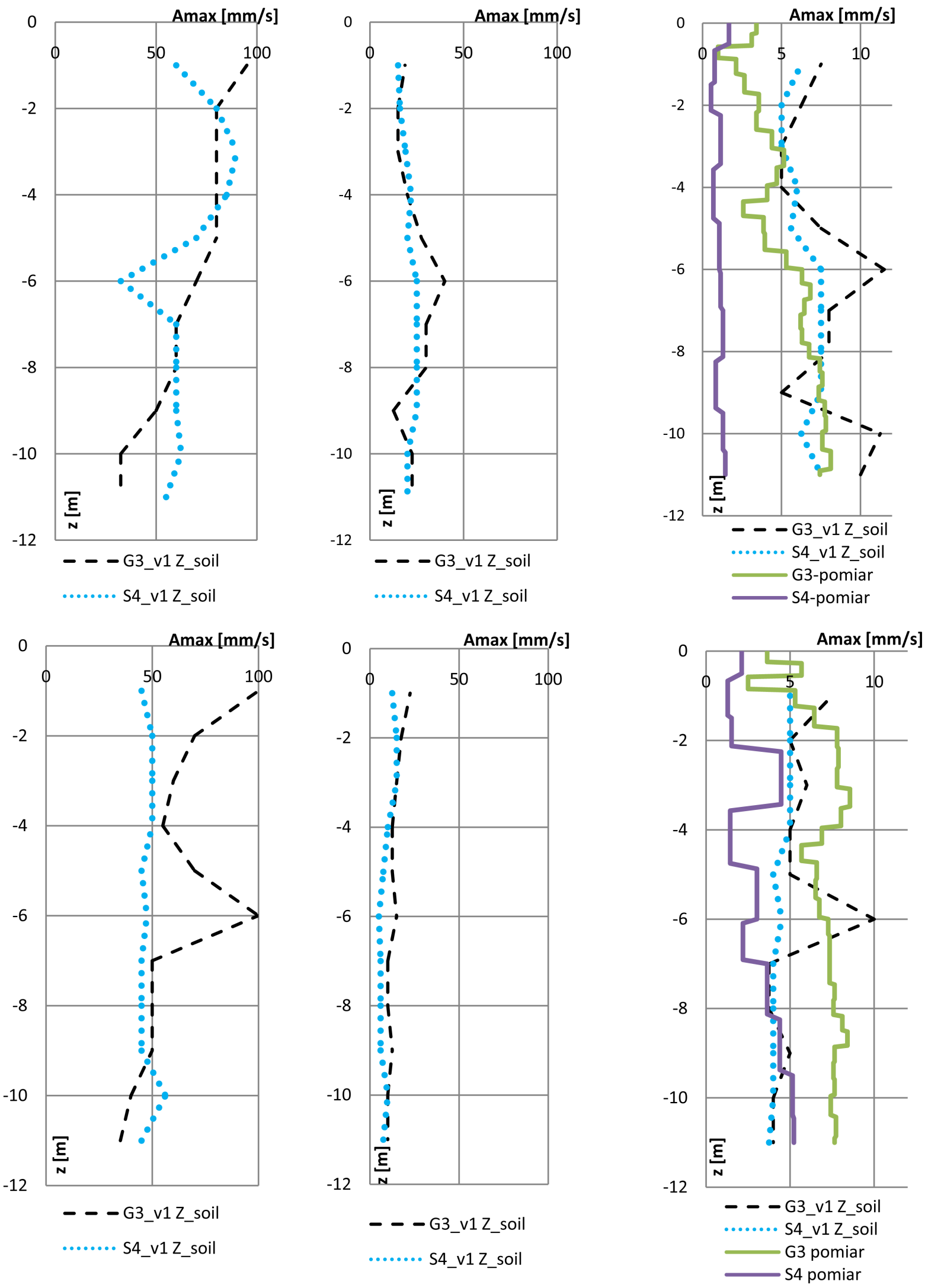

Figure 20. Changes to the maximum amplitude of the vibration velocity with respect to depth $\mathrm{m}$ for driving the piles G3_v1 and S4_v1 modeled in Z_Soil, $5 \mathrm{~m}, 10 \mathrm{~m}$ and $15 \mathrm{~m}$ (from left) and the X and Z direction (from the top). 
A. Jaroń et al.
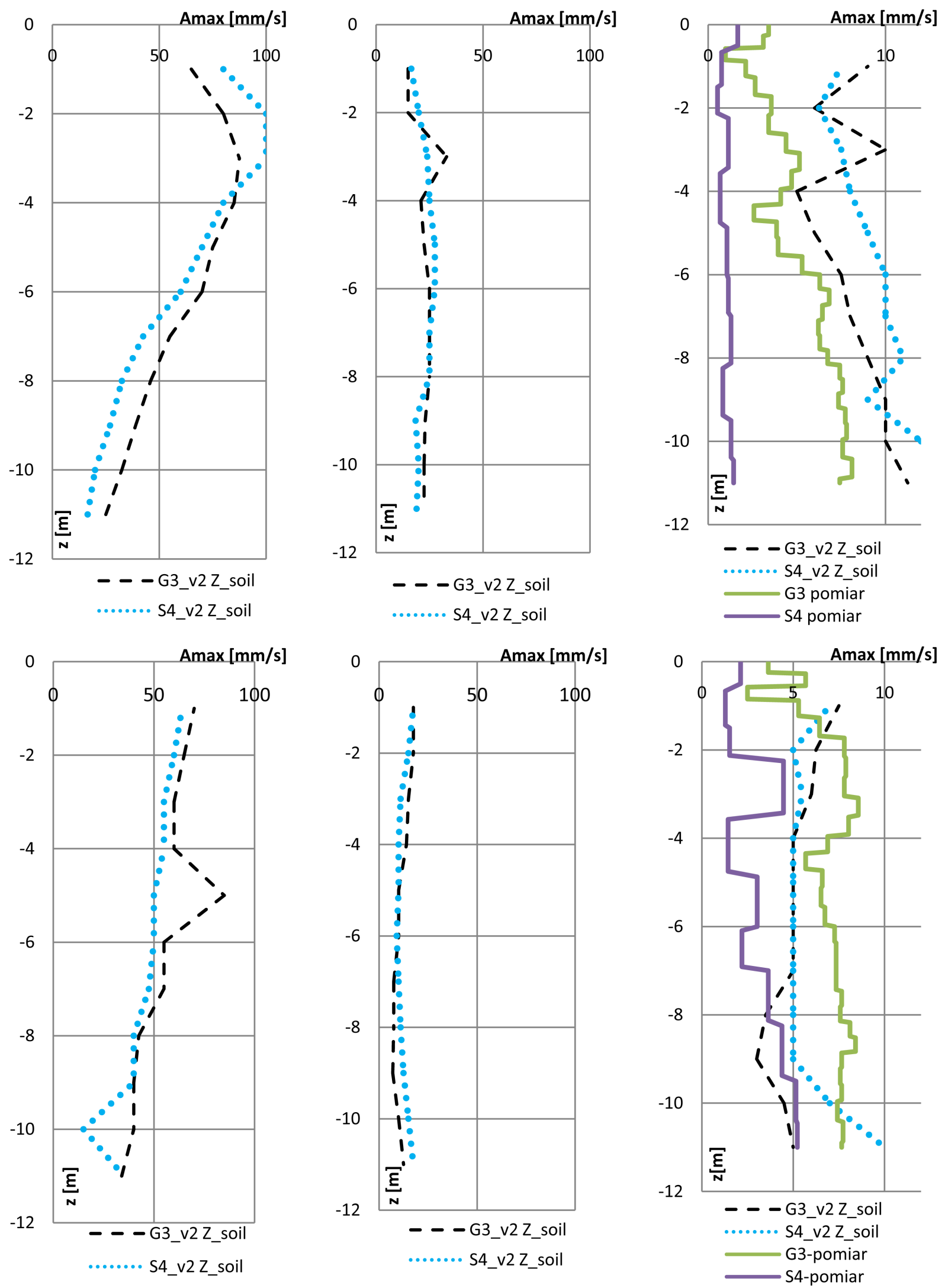

Figure 21. Changes to the maximum amplitude of the vibration velocity with respect to depth $\mathrm{m}$ for driving the piles G3_v2 and S4_v2 modeled in Z_Soil, $5 \mathrm{~m}, 10 \mathrm{~m}$ and $15 \mathrm{~m}$ (from left) and the $\mathrm{X}$ and $\mathrm{Z}$ direction (from the top). 
- for piling without water jet-assisted driving elements of the contact zone are consistent with the parameters of land, which is located piles,

- for piling water jet-assisted parameters $\varnothing$ and $\mathrm{c}$ are close to 0 ,

- They are correct. This is evidenced by the results showing lower values of the amplitudes of the sheet pile S4_v1 and S4_v2 in comparison to G3_v1 and G3_v2, reflecting the trend in the measurements in the field, where the value of 54 are smaller than the G3.

- amplitudes piling v2 are equal to or smaller than those v1. Thus, the assumption of the division calculations for two different versions of the number of nodes (1471 and 2936) and the width of the contact zone (10 m and $100 \mathrm{~m}$ ) may also affect the obtained results;

- due to the stochastic nature of the soil medium and the specificity of vibratory driving the piles, as well as a number of simplifications necessary numerical modeling, modeling results reflecting the reality is fundamentally flawed. Nevertheless, it can serve as an effective tool for forecasting restricted zone outflows dynamic.

\section{Conclusions}

Lower vibration and noise levels connected with a significant reduction of sheet pile driving time prove the use of jet-assisted driving process justified. The conclusions are as follows:

- Jet-assisted sheet pile driving reduces vibration and noise levels, and significantly improves the sheet pile driving rate. The time of S4 sheet pile vibratory driving was $40 \mathrm{~s}-180 \mathrm{~s}$ shorter in comparison to G1 - G5.

- In jet-assisted driving, the sheet pile toe shape influences the results. The S4 sheet pile, which offers the highest flow of water, also offers the best results.

- Jet-assisted driving was used on non-cohesive soils, well compacted and waterlogged, which are perfect for sheet pile vibratory driving. There were some concerns that no vibration reduction would occur below the ground water level. These concerns have not found confirmation. The efficiency of jet-assisted sheet pile driving on waterlogged soils is slightly lower, but no significant difference has been observed.

- Jet-assisted driving has significant influence on sheet pile driving rate, which reduces the duration of vibration and noise. This may be indicated using the total vibration amplitude parameter.

- Measurements were performed at the distance of $10 \mathrm{~m}$ to $15 \mathrm{~m}$ with a 10 second interval. Only the measurement at the distance of $5 \mathrm{~m}$ was performed with a $1 \mathrm{~s}$ interval. The connection of measurement points with 1 and 10 second interval leads to a closed plot, in which the abscissa represents the vibration velocity value and the ordinate indicates the depth, at which the sheet pile toe was located during measurement. The plot area with the interval of 1 $s$ covers $87 \%$ of the plot area with the interval of $10 \mathrm{~s}$.

- There is a visible correlation between the decrease of vibration reduction ef- 
ficiency for sheet piles installed through jet-assisted driving with depth, which is related to ground water, but also to the increase of sheet pile lateral surface and clutch resistance with the simultaneous decrease of resistance under the toe. This tendency is visible on the plot shown in Figure 17.

- With time, the occurrence of friction at the sheet pile clutches causes the vibration level to increase by $100 \%$. On the other hand, the presence of ground water is helpful. Also using new sheet piles instead of used sheet piles has a significant influence on these values. The vibration levels for the GU20N sheet piles, in which the single sheet pile surface area is $103.4 \mathrm{~cm}^{2}$ are more similar than for the used GU16-400 sheet plates, in which the cross-section surface area is $78.9 \mathrm{~cm}^{2}$.

- In the case of new GU20N sheet piles (G2, G3, G4, G5), the measured vibration levels were sometimes lower with regard to clutch friction than in the case of a single GU20N sheet plate (G1). In the case of used GU16-400 sheet pile, it was the opposite.

- The sheet pile shape and dimensions influence the obtained vibration levels. While comparing the values for the sheet piles driven individually (without resistance at the clutch), i.e. G1 and G62_1, one may notice better results of the G1 sheet pile for the directions $Y$ and $\mathrm{Z}$ in comparison with the G62_1 sheet plate. Despite the cross-section area of the G1 being larger than of the G62_1 by approx. 30\%, the results are better by approx. 30\% for the direction $\mathrm{Z}$ and $60 \%$ for the direction $\mathrm{Y}$, but worse for the direction $\mathrm{X}$, considering the $A_{\max }=$ PPV values. The time of sheet pile driving is almost identical.

- By performing an analogical comparison for the sheet plates driven in the clutch of a previous sheet pile, i.e. for G2 and G62_2 sheet piles, one will notice better results of the $\mathrm{G} 2$ sheet pile for the directions $\mathrm{Y}$ and $\mathrm{Z}$ than with the G62_2. The G2 results are better than the G62_2 results by $42 \%$ for the direction $\mathrm{Z}$ and by $46 \%$ for the direction $\mathrm{Y}$, but worse by $80 \%$ for the direction $\mathrm{X}$, considering the $A_{\max }=P P V$ values. The sheet pile driving time for the G2 was 47 seconds, i.e. $23 \%$, shorter than for the G62_2.

- Results of numerical modeling presented in paper are promising. Further attempts to develop a predictive model of dynamic range zone of influence based on more research will give a precise answer to the frequently asked question about the possibility of driving the vibrating steel sheet piling.

\section{Acknowledgements}

Authors are grateful to "Zakład Robót Inżynieryjnych Henryk Chrobok i Hubert Chrobok sp.j." company for allowing us necessary equipment and input during field test. More over we would like to thank Jarosław Rybak (PhD) for helping us during measurement process.

\section{References}

[1] Viking, K. (2002) Vibro-Driveability-A Field Study of Vibratory Driven Sheet Piles in Non-Cohesive Soils. Ph.D. Dissertation, Department of Civil and Architec- 
tural Engineering Royal Institute of Technology (KTH), Stockholm, Sweden.

[2] ArcelorMittal (2004) Installation of Steel Sheet Piles. Reprint. http://sheetpiling.arcelormittal.com/uploads/files/ee6cad78a66c122d7eb19082f51d0 375.pdf

[3] Ciesielski, R., Kwiecień, A. and Stypuła, K. (1999) Propagacja drgań w warstwach przypowierzchniowych podłoża gruntowego-badania doświadczalne In Situ. [Vibrations Propagation in Subsoil Superficial Layers-Experimental Studies In Situ.] Monograph, Krakow University of Technology Publishers, Krakow, 263.

[4] (2013) State Highway Construction and Maintenance Noise and Vibration Guide v.1. New Zealand Transport Agency, ISBN 978-0-478-38065-1.

[5] Zeilinger, H. (2009) The Vibro-Jetting Driving Method. International Foundation Congress and Equipment Expo, Contemporary Topics in Deep Foundations, Publications (GSP) 18, ASCE 311-319. https://doi.org/10.1061/41021(335)39

[6] Athanasopoulos, G.A. and Pelekis, P.C. (2000) Ground Vibrations from Sheet Pile Driving in Ubran Environment: Measurements, Analysis and Effects on Buildings and Occupants. Soil Dynamics and Earthquake, 19, 371-387.

https://doi.org/10.1016/S0267-7261(00)00008-7

[7] White, D., Finlay, T., Bolton, M. and Bearss, G. (2002) Press-in Piling: Ground Vibration and Noise during Installation. Proceeding of the International Deep Foundations Congress, Orlando, USA. ASCE Special Publication 116, 363-371.

[8] Hiller, D.M. and Hope, V.S. (1998) Groundborne Vibration Generated by Mechanized Construction Activity. Proceedings of the Institution of Civil Engineers, 131, 223-232. https://doi.org/10.1680/igeng.1998.30714

[9] Eurocode 3 (1992) Design of Steel Structures. Chapter 5, Piling, DD ENV 1993-1$1: 1992$.

[10] Svinkin, M.R. (2004) Minimizing Construction Vibration Effects. Practice Periodical on Structural Design and Construction ASCE, 9, 108-115. https://doi.org/10.1061/(ASCE)1084-0680(2004)9:2(108)

[11] Woods, R.D. (1997) Dynamic Effects of Pile Installations on Adjacent Structures. NCHRP, 253: National Academy Press (Transportation Research Board), Washington, D. C., 86 p.

[12] Holeyman, A.E. (2000) Vibratory Driving Analysis. In: Niyama, S. and Beim, J., Eds., Application of Stress-Wave Theory to Piles, Balkema, Rotterdam.

[13] Meijers, P. (2007) Settlement during Vibratory Sheet Piling. PhD Dissertation, TU Delft Repository.

[14] Vanden Berghe, J.-F. (2001) Sand Strength Degradation within the Framework of Vibratory Pile Driving. PhD Dissertation, The Faculty of Applied Science, Universite Chatolique de Louvain, Belgium.

[15] Legrand, C., Van Rompaey, D. and Menten J. (1994) A Comparison of Different Sheet-Pile Installation Methods. Fifth International Conference \& Exhibition on Piling and Deep Foundations, Bruges, Belgium, (DFI), 762 (36).

[16] Pieczynska, J. and Rybak, J. (2011) Dynamic Monitoring of Structures Adjacent to Geotechnical Work Sites. 10th Slovak Conference on Geotechnical Engineering, Geotechnical Problems of Engineering Constructions, Bratislava.

[17] Januszewski, M. (2011) Nowa polska grodzica na trudne grunty-GU18N. [The New Polish Sheet Pile to Difficult Ground Conditions-GU18N.] ArcelorMittal Commercial Longs Polska, Geoinżnieria Drogi Mosty Tunele, 4, 36-38.

[18] Jastrzębska, M., Łupieżowiec, M., Uliniarz, R. and Jaroń, A. (2014) Analysis of the 
Vibration Propagation in the Subsoil. XVI French-Polish Colloquium of Soil and Rock Mechanics: Multiscale Modelling in Soil and Rock Mechanics, Montpellier. Studia Geotechnica et Mechanica, XXXVI, 9-18.

[19] Bzówka, J. (2009) Współpraca kolumn wykonywanych techniką iniekcji strumieniowej z podłożem gruntowym. [Cooperation between Jet Grouting Pile and Subsoil.] The Silesian University of Technology Publishers, Gliwice.

[20] Zimermann, Th., Truty, A., Urbański, A. and Podleś, K. (2010) Z_Soil.PC 2010 3D User Manual, Theory, Tutorials and Benchmarks, Data Preparation. Elmepress International \& Zace Services Ltd., Switzerland.

[21] Łupieżowiec, M. (2012) Modelowanie rozchodzenia się drgań powodowanych przez konsolidację dynamiczną w ujęciu MES. [Modeling of the Propagation of Vibration Caused by the Dynamic Consolidation in Terms of MES.] Inżynieria Morska i Geotechnika, 4, 352-357. 


\section{Appendix A}

1) Maximum amplitude-Complete measurement

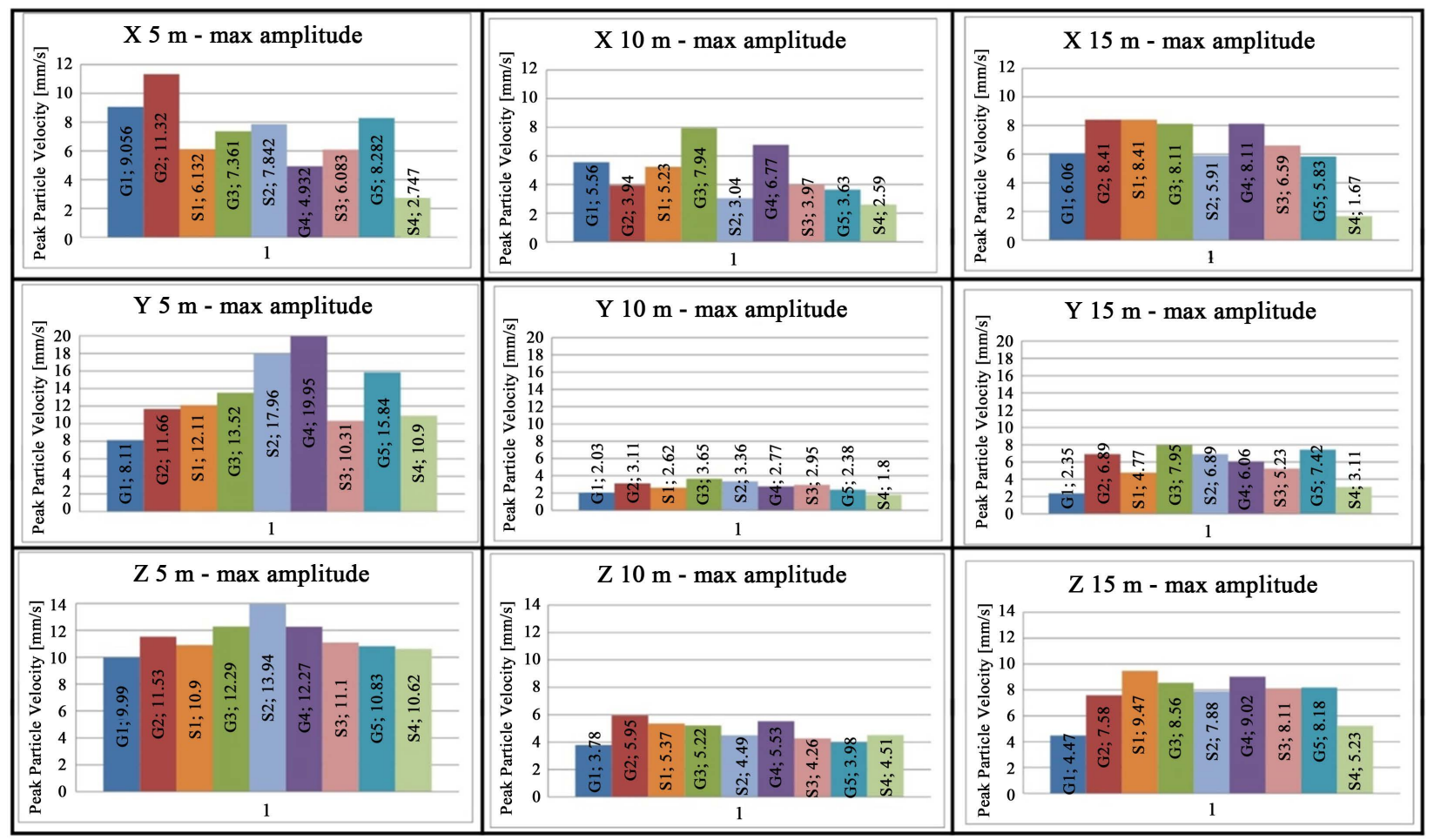

2) Average amplitude-Complete measurement
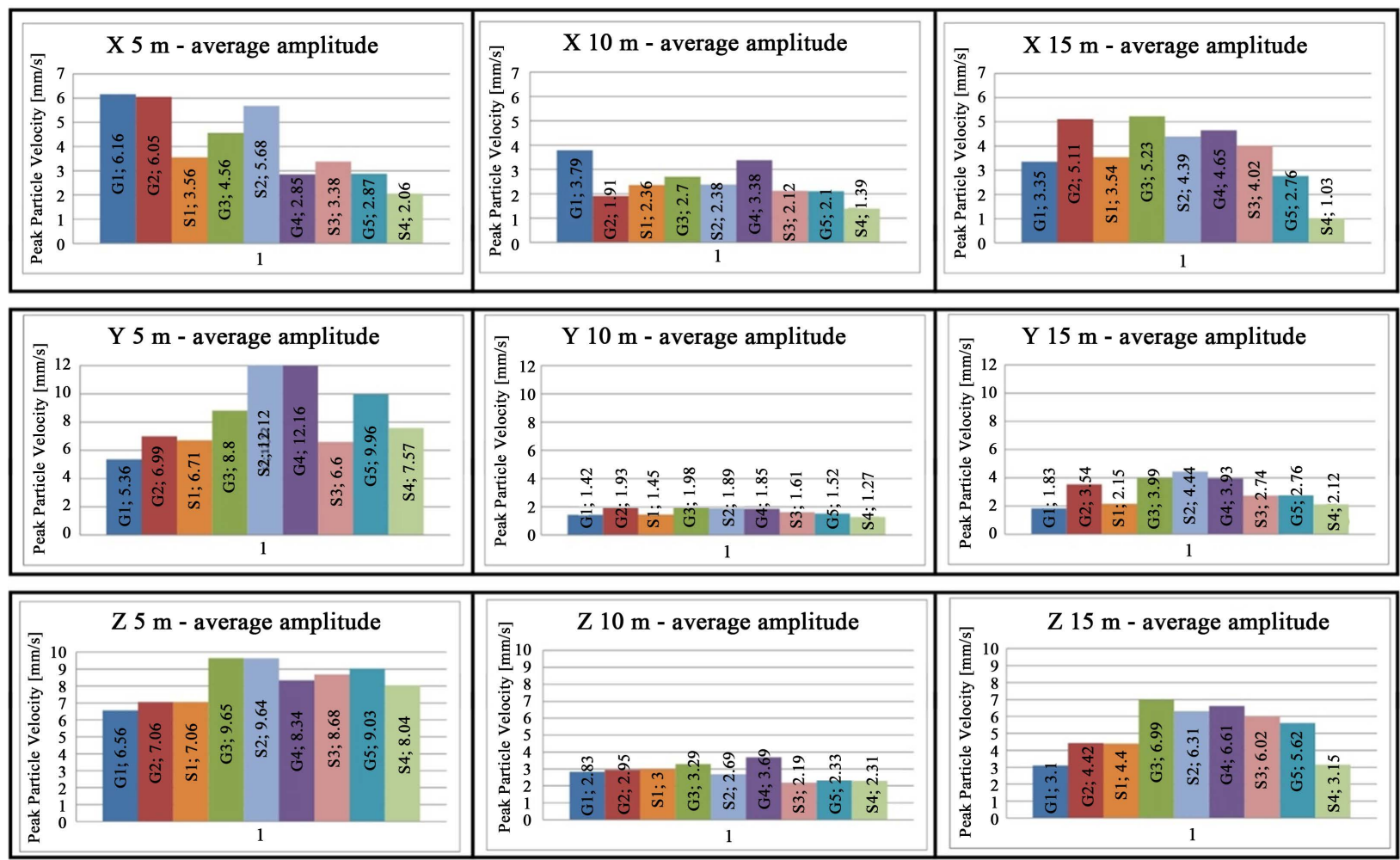


\section{Appendix B}

1) Maximum amplitude-The first 4 meters

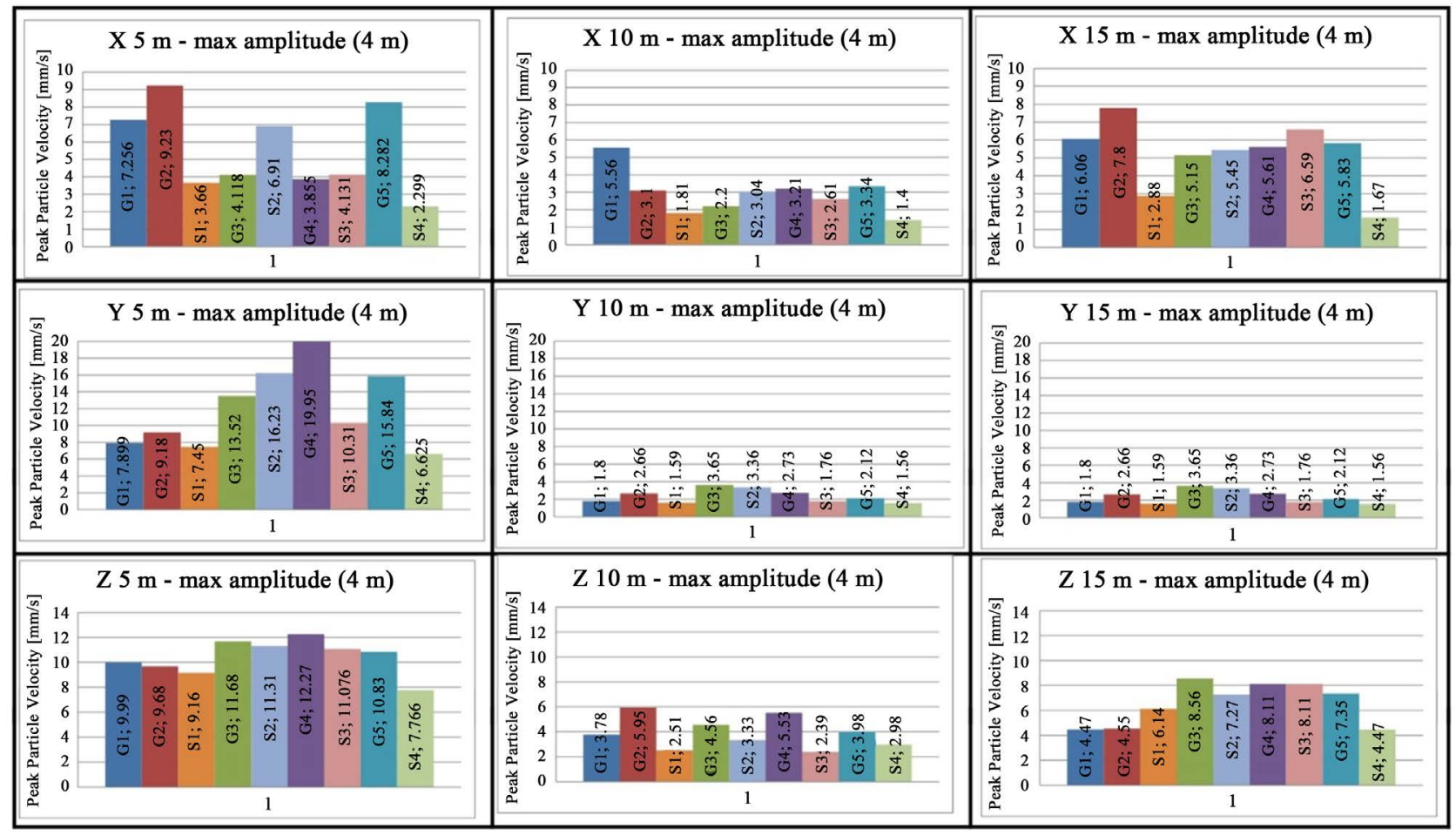

2) Average amplitude-The first 4 meters

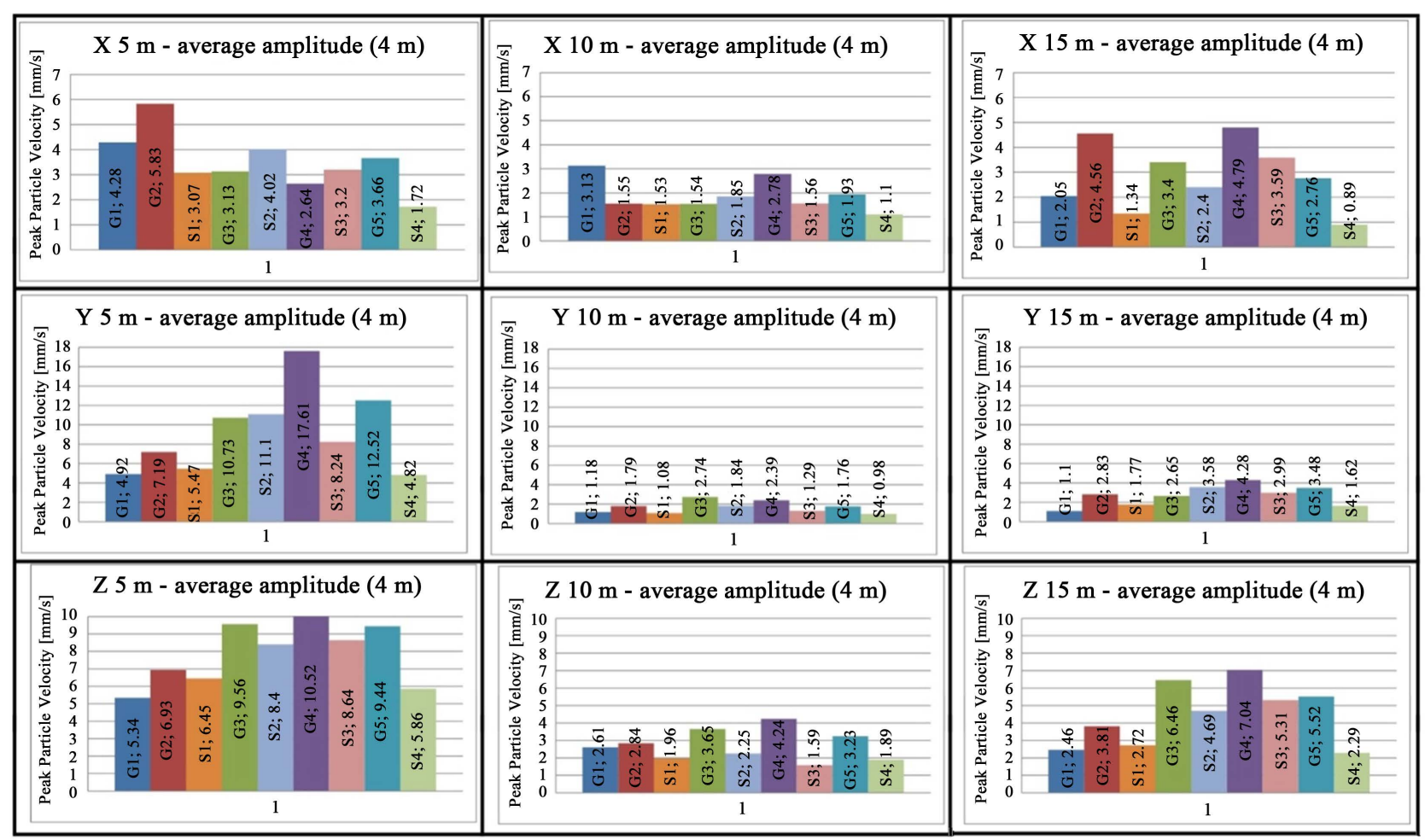

